\title{
SYMBOLS IN TATAR POETRY OF 1920-1950's: THEIR TYPES, FUNCTIONS AND NOMINATIVE MEANINGS
}

\author{
Nurfiya Marsovna Yusupova, \\ Kazan Federal University, \\ 2 Tatarstan Str., Kazan, 420021, Russian Federation, \\ faikovich@mail.ru.
}

\begin{abstract}
The article presents the results of the symbolic system analysis that was carried out as a part of 1920s and 1950s Tatar poetry case study. The study focuses on poetry by Kh. Taktash, M. Gafuri, Kh. Tufan, M. Dgalil, A. Fayzi, F. Karim and others. The analysis enabled us to identify national specific features of symbolization in Tatar verbal art. Although in the 1920s Tatar poetry began to function as one of the socialist culture branches, the connection with the past was not lost largely due to the stability of traditions in Tatar poetry, formed in the early $20^{\text {th }}$ century. There is a strong connection with those images, motifs and symbols that are rooted in folk or Islamic culture as well as the common Turkic mythology. The technique of symbolization is similar to the mechanism of intraliterary synthesism. At the same time, ideological symbols emerged due to the change of literaryaesthetic and socio-cultural landmarks. Even though Tatar literary symbols frequently perform the same function, their numerous authorial semantic variations appear in the course of text transformations. Moreover, using folklore images-symbols is perceived by Tatar poets as a way to "mitigate" sharp transitional phenomena, as well as preserve the content and formal artistic traditions of national poetry. References to folk art and use of images-symbols that are traditional for Tatar literature enable the poets not only to make ideological and mythological images more vivid with details, but also to overcome political schematism. Moreover, a conscious look at ideology can be traced in folklore images-symbols that act as "spokesmen" of the "anti-ideological" author's position. A critical look at everyday problems through the prism of the nation's destiny, morality and traditions of the people deepens the content, as shown by hidden political meanings in Tatar poetry of the 1920s and 1950s.

Thus, the changes of sociocultural landmarks facilitate both the search for ideological universals, symbolic structures and the development of ideological content. At the same time, Tatar poetry makes an attempt to protect literary traditions, and this attempt is clearly manifested in preserving the foundations of the system of national symbols, primarily by using images-symbols genetically related to the folklore traditions, symbolizing the beginning of the $20^{\text {th }}$ century.
\end{abstract}

Key words: Tatar poetry, symbol, transformation, image, personality concept, function, nominative meaning.

The study was carried out as part of a grant from the Russian Foundation for Basic Research and the Government of the Republic of Tatarstan (research project No. 18-412-160008).

Tatar poetry of the 1920 s and 1950 s went down the history as a remarkable period in literature. It includes two stages: the 1920s and 1930s and then the poetry of the war and post-war years. These two stages, being a single entity in terms of their ideological and aesthetic features, develop as a continuation of each other. This division remains relevant for the system of symbols as well, since the changes that occurred at that time correlate with transformations in sociocultural and literary-aesthetic conditions as well as philosophical worldview. Under those circumstances a literary word, which is sensitive to changes in society, begins to look for new ways of illuminating the reality that lost its path of development together with its logical structure [Stetsenko, p. 106]. According to the literary critic, in this context the authors' searches in the 1920s and 1950s could be characterized as a "wreck" of the ideals of the 20th century.

M. Golubkov defines the parallel development of the two trends in the Russian literature of the 1920s and 1930s: on the one hand, the aesthetic views did not lose their relevance, on the other hand, there was an increase in the ideological content and its characteristic visual means [Golubkov, 1992, p. 5]. As a result, two trends, two "cultures" were formed within the framework of one literature: they came to represent the struggle between the old and the new [Golubkov, 2001, p. 49]. Under those circumstances the culture of the word "experienced a rapid and intense development, which came about when the modern traditions of the previous stage merged with the 
powerful energy of the period of social changes" [Balashova, p. 10]. Those changes were somewhat similar to the ones in Tatar literature, but occurred in a slightly different way.

The system of symbols in Tatar poetry of the $1920 \mathrm{~s}$ and $1950 \mathrm{~s}$ is characterized by the conventional images of ideological content and the continuation of classical traditions of the early 20th century, the emergence of socialist realism from the schematic framework and the return to classical traditions by means of referring to symbols of oral folk art. While evaluating the development of that system of symbols one can adhere to the theory of the "meeting of opposite processes" by Yu. Borev [Borev, p. 463]: in the system of symbols new, ideological, classical and aesthetic canons and techniques are combined with the nominative meaning and functions. S. Semenova connects classical, folklore traditions of Russian literature with the works of representatives of so-called "village poetry" [Semenova, p. 41]. In Russian literature "village poetry" and proletarian literature make up two separate domains, but in the Tatar environment they are interconnected. In the works of the same writer ideological and folklore symbols develop in parallel with classical traditions.

In the literature of that period several types of symbols were made active use of. That is, mythological symbols were employed in accordance with classical traditions of the early 20th century; the symbols of ideological content were formed; the symbols of oral folk art were revived to mark the renewal of the romantic poetry traditions, but these symbols now performed a completely new function - the "destruction of ideological ideas".

Symbolic and romantic works still referred to myths and mythological symbols were used extensively (Kh. Taktash "Kuktan sorelgannar" ("Banished from Paradise"), 1918, "Zhir ullari tragediyasi" ("Tragedy of the Earth Sons"), 1923; M. Jalil "Kabil ham Habil" ("Kabil and Habil"), 1923, "Yana tarikhy anbiya" ("The New History Prophet"), 1923; M. Gafuri "Kuk zhyrlary" ("Sky Songs"), 1923, etc.). The content of these works is deep and implies different interpretations; the characters featured in these pieces are quite complex. They develop the philosophical traditions of literature of the beginning of the century. In such works folklore as well as mythological plots and images serve the purpose of evaluating a certain period of writers' lives, employing the method of internal literary synthesis used for symbolization.
In his article written in 1929, F. Burnash explains this phenomenon as influenced by the "Dardemend School". He believes that this feature can be found in the first works of A. Sagdi, Chenekai, K. Najmi, in addition to the works by Taktash [Burnash, p. 236].

Kh. Taktash completed his "Kuktan sorelgannar" ("Banished from Paradise") in August 1918, but it was published only in 1923. In the story, which is borrowed from mythology, Gazrail, who always does Allah's bidding and kills people, receives an order to destroy a man and a fair girl, an angel. As soon as he sees the girl, Gazrail falls in love with her and refuses to fulfill Allah's order. In revenge, Allah turns the girl into a stone. Gazrail, convinced of Allah's wickedness, rebels against him; he rejects his evil intentions, makes fiery speeches, stops killing people, and starts telling humans the truth. The poet uses this symbolic context to emphasize ideas that resonate with that period: the images of Allah and Ghazrail symbolize spiritual renewal of man, the rebel uses the opportunities provided by the revolution to fight the past and the forces that try to destroy justice and eclipse the mind of man.

Kh. Taktash's poem "Tan kyzy" ("The Girl of the Dawn") (1921) was inspired by mythological traditions. Eastern mythological motifs symbolize the romantic love of the protagonist for the girl of the dawn. The symbol of flame, the image of a red flower are used figuratively to praise love: Peri girl! Why did you meet me, / Having red flowers in your hands, / You threw your flowers away and smiled / Why did you hide in the sunrise? [Taktash, p. 109].

Continuing the romantic traditions of the early 20th century, the poet talks about his love for the Peri girl (a mythological creature). As known, a Peri in Persian and Iranian mythology is the symbol of "the guardian who was temporarily banished from paradise for protecting people from evil spirits" [Bertels, p. 142-144]. The writers of the early 20th century actualize the image of the girl in terms of "beauty and sincerity" [Kolobaeva, 2000, p. 157]. Epithets and techniques, which were used in describing the Peri, create a two-sided image. First of all, it is regarded as divine love, secondly, as a feeling for a simple earth girl (Gol) (Flower). Similar to Russian symbolists, the lyrical hero creates the image of the girl that is an impossible ideal, a source of sacred love that is close to madness and that makes him get rid of his egoism. The poem falls in line with and further develops V. Soloviev's philosophy of love. Later the image 
of the Girl of the Dawn is used in the same semantic form in Kh. Taktash's poem "Urman kyzy" ("The Forest Girl") (1922) and M. Jalil's "Djil" ("Wind") (1937).

Kh. Taktash's "Zhir ullari tragediyasi" ("The Tragedy of the Earth Sons") (1921) incarnates the concept of a new type of a rebellious personality and a fighter [Khabutdinova, p. 12], which is more than just a mythological symbol. These devices symbolize a certain idea. "Symbolism deepens, improves. It is first found in the work "Zhir ullari". It then appears in newspapers and magazines; the talented poet Taktashev has a special place in our poetic world"- wrote G. Ibrahimov in 1924 [Ibragimov, p. 412]. One group of these abstract ideas shows that we need to obey dogmatism and fate, yet another group urges us to fight against them and raises the problem of personal freedom. It was for this phenomenon that G. Nigmati criticized Taktash: "Taktash is under the strong influence of old literature. We can see the influence of mysticism on his work... 'the canon of Djabrail' (Gabriel) becomes a separate symbolic image" he wrote [Nigmati, p. 73].

In the structure of the poem Idea-Gazazil (in Muslim mythology it means a fallen angel) is a symbol of the fight for freedom and happiness. Besides, being the model of a new life, this image represents beautiful and light palaces, flower meadows and winds of freedom. This is how the piece conveys revolutionary ideas and proves that revolution is the path that leads to freedom and happiness:

\begin{tabular}{|c|c|}
\hline $\begin{array}{l}\text { Let's find a way } \\
\text { Out of this damned } \\
\text { place } \\
\text { To happiness } \\
\text { Let's fly together to a } \\
\text { world of free life! }\end{array}$ & $\begin{array}{l}\text { Where is neither Allah, } \\
\text { nor canon, } \\
\text { No worries, sorrows, no } \\
\text { sadness; } \\
\text { Where we will live } \\
\text { freely, } \\
\text { Like fresh, free wind ... } \\
\text { [Taktash, p. 80-81]. }\end{array}$ \\
\hline
\end{tabular}

These images can be interpreted in different ways. Literary experts claim that the poem "Zhir ullari tragediyasi" ("The Tragedy of the Earth Sons") was written under the influence of Byron's poem "Cain" [Khalit, p. 21]. Young poets see similarities between revolutionary and rebellious ideas, each writer feels like "a prophet-hero capable of changing the rules and life in general" [Zagidullina, p. 177]. In this light Adam and Eve are symbols of humanity, and the Caucasian mountain is a border between the good and the evil, cowardice and courage in the soul and life of every person. Idea-Gazazil is the symbol of mind and freedom, while Gazrail (Kanun) is the symbol of fear and slavery. The author uses them to convey his own belief: misfortunes of people are the result of their submission to various canons and cowardice, and the path to happiness begins with winning a victory over their own fear.

The tendency to use plots and images of folk art at the level of symbols can be observed in M. Jalil's libretto "Altynchech" ("The Golden-Haired Girl") (1940) based on a mythological story about Djik-mergen (a historical poem). In 1937 he was criticised by "puppets of ideology" for this. In his article "A Letter to the Editor. On the Tatar Opera Studio" published in "The Kyzyl Tatarstan" ("The Red Tatarstan"), F. Mosagit, a supporter of vulgar sociologism, calls the works of Jalil "the remnants of bourgeois views" [Mosagit, 1937] and criticises "Balykchy kyz" ("A Fisherwoman") and "Altynchech" ("The Golden-Haired Girl"). The character of Tugzak ana ("Altynchech" ("The Golden-Haired Girl")) is seen as a persistent hero with a strong spirit who withstands life tests and symbolizes the Tatar nation: You wanted to destroy my tribe, / Here I am, here are my sons. Nation never dies [Жəlil, p. 319].

While Djik-mergen is its worthy continuation, Altynchech becomes the symbol of freedom. It is love for freedom and happiness. Altynchech is Djik's hope, liberty and joy. Consequently, it is the nation's liberty, hope and joy too. Jalil depicts his contemporaries' life in subjective content as he describes Tatar nation's fight for freedom and independence. Moreover, he enriches his work with the idea of his nation being as brave as Tugzak ana.

Furthermore, Tatar poetry reflected the hope for better future, worshiped the political situation in the country and the idea of creating a communist society. As F. Galimullin points out, literature in the late 1920s served political and ideological purposes [Galimullin, p. 44]. The situation was similar to what was happening to Russian literature: poetry became a platform for aesthetic embodiment of reality, reporting state myths to a wide range of readers [Gunter, p. 7] and expressing ideological slogans in poetic language [Gacheva, p.149]. After 1920s semantic-syntactic culture started developing more rapidly [Nigmatullina, p. 170], therefore, symbols in ideological content increased in numbers.

Reality, shaped by revolution, was described in upbeat tones, hence publicism-agitation and satiriccomic poems. The symbols of dawn, sun and day acquired a revolutionary meaning. These tradition- 
al images were often used differently from their previous meanings. In the second half of the 1920s they were used in the works of literature in the urge to abandon the past after the social revolution, to create a different world, a new life, ascertain the policy of striving for communism. In the content like this the pathos of victory, pathetics, and romantic revolutionary spirit prevailed.

Researchers call the art of the 20th century the art of mythologization. "The fundamental culture in the 20th century is totally mythologized, the myth becomes the primary element of literary, philosophical, ideological and even political constructions" [Halizev, p. 8]. Ideological motifs that accompany the epoch come to the fore: aspirations for the bright future, sacrificing oneself in a sacred battle, the beauty of the native land and work. These motifs comprise a new group of mythological images - the symbols of ideological content like country, banner, fighter and enemy. In their strive to show their emotional attitudes towards the confrontation of the old way of life with the new socialist order, poets choose images that embody the essence of historical processes. As a result, at the birth of the poetic thought two colours are used to influence people's souls: red and black, present festive life and the past life of suffering, red heroes and fierce enemies, love for the new and hatred for the past.

Futuristic and imagistic experiences make ideological symbols more enriched. In 1910 O. A. Kling was studying the development of symbolism and post-symbolism trends and came to the following conclusion: "the past modernist experience and futurism, which has chosen to break its ties with symbolism, stem from symbolist traditions" [Kling, p. 40]. According to literary critics, futurism emerged as a continuation of the symbolism poetics [Sarukhanian, p. 29], futurist poets continued to use symbolistic ideals in transformed forms [Gacheva, p. 14]. This phenomenon allows us to enrich the nominative function of symbols with new meanings.

When it comes to Tatar poetry, this trend is illustrated in the works of Kh. Tufan, K. Nadjmi and M. Jalil. A young poet Khasan Tufan deliberately uses theoretical works of Russian formalists and new trends based on changes in the poetic form (first of all, imagism and futurism), purposefully relying on literary novelties. He is considering the possibility of creating new imagery within new trends and sees these trends as a means of changing and improving national poetry. Tufan begins to enjoy the process of creating complex images: he makes associations by comparing certain phenomena and concepts with an emotional assessment. His imagery has such symbolic details as "night - a red cow", "fire coming out of the factory chimney - black blood flowing from the neck of a cow"; "Spring thoughts swell like wheat grains / grown / at the beginning of Kazan", "Our feelings are bleeding / due to the failure", "Mother is a village, father - a factory - the father of the son-in-law / West is a daughter-in-law, / the sonin-law is Asia". These images allow him to fulfil his desire to describe the new life in a new way.

In Tufan's poems written in the 1920s, one cannot fail to notice a constantly repeated opposition of the "past-present" and "old-new". Tufan considers this opposition to be a peculiar figurative way and a symbolic model. This juxtaposition lies at the heart of his poems "Arysh tavysh bira" ("Rye Gives Voice") (1926), "Dachada" (In the Country) (1926), "Konchygyshnyn yana balasy" ("A New Child of West") (1927), "Akkordlar" ("Chords") (1928-1930), "Ellar itegende" ("At the Bottom of Years") (1925), "Barabyz" ("We Are Going") (1925), "Tatarstanda" ("In Tatarstan") (1925). In the latter work the "past-present" conflict is worded as "now-then" and can be found in the formations of separate parts, as well as the structure of the poem. Symbolic details like $a$ swamp, a governorate and wintering become the signs of the past and describe the past like a source of unhappiness, while the present makes people happy. The symbolic images and descriptionwords like tractor, march help to get the meaning across. The poet describes the past like a field of blood left over from the Khans; like grief and curses in the autumn village; like a man slaving away on a field; like knives covered in blood; like sorrow, orphanhood and dark night. The present is the time when weddings are celebrated in the west and east of Tatarstan; it is the time of tractors in the village and a man working on the land that he is the owner of; it is the time of March greetings and laughter; Tatarstan is a father. These details are used to create the images of the past and the present. A farewell phrase, similar to a rhetorical appeal, associates farewells and partings with the past. In his poem "Barabyz" ("We Are Going") (1925) the contrast between the past and the present is the focus of attention. Such details as $a$ horse, sorrow and silence help to create the picture of the past, while the present is depicted with such words as a tram, an engine, a banner, a propeller, a factory and a drum. The happiness of the lyrical hero is triggered by his decision to move on to- 
wards the bright future: history is silent and drear, while happiness is associated with the industrial development. The joy of the triumph of socialism, the enthusiasm of industrialization, the hatred for the old life, the deep faith in the victory of the novelty brought about by the revolution and the debate with the old literature - all these literary details serve one purpose, that is, to increase the sense of joy.

In the poem "Bodre Konner" ("Curly Days") (1926) Tufan describes good years after the revolution. Besides, spring becomes a symbol and image of a beautiful bright future - this is a modern connotation of the traditional meaning. The beauty of today is emphasized with the symbolic images of freedom and work, the sun is the road that leads to the sunny spring, which is really the path to the beautiful future. In the poem "Ellar itegende" ("At the Bottom of Years") (1925) the opposition of "past - present" is represented with a peculiar image. The past is a child's memory about the events before the revolution; the reason for the child's sorrow is the loss of its father. All these influence the fate of the country, the nation and its people. The poet expresses his thoughts using symbolic images. The wind of the past is perceived as a force that ruins the country, "disturbs peace", and, in general, becomes a mark of revolution:

\begin{tabular}{|l|l|}
\hline The Wind. A thick wind. & "Siberia". \\
The wind blows a straw & And I have no idea, \\
- & What "Siberia"is?.. \\
Oakum old house away. & And the wind, the wind \\
Clouds are sifting snow. & is a broom: \\
Travellers are coming & It has swept people's \\
from the city... (...) & footprints \\
& [Tuf 34]. \\
\hline
\end{tabular}

Within the framework of sociological aesthetics such image-details as winter, night are used to reveal the ugliness of the past life, whereas the dawn will mark the bright future, which the revolution will lead to. The present is recreated in the narrative on behalf of the old "me" and is embodied in such images and details as freedom, struggle, novelty and the road leading to the future. The poem manifests the idea that the new life will bring people happiness.

The image of the world, which is reflected in M. Jalil's works, is recreated using the same juxtaposition of the "past / present". In his poems "Utkan konnardan" ("From the Past Days") (1924), "Ati ulgach" ("After My Dad's Death") (1924), "Beznen avyl" ("Our Village") (1927) the new life is praised and the past is rejected. The symbolic images of a dried birch and an old plough symbolize loss and the end of the past, while the images of a young birch and a tractor become the symbols of the present and future. In such poems as "Sukachy ugly" ("The Son of a Ploughman") (1923), "Boz aga" ("Ice Movement") (1923), "Iske Seber zhyry" ("The Old Siberian Song") (1924) the author expresses his sympathy with the past and sees the present as a period of struggle. There is also the feeling of pride. The images like a hungry and sick "dad", worn down by work, "mom", "plough" and "black life" become the symbols of the past. As he speaks of the present, the poet uses the images-details of Lenin, an industrial plant and a wedding celebration.

The archetype theory, which is well-known in the world culture, influenced the mythologization of the images of travelers in lyrical works that praise the new life. Owing to the mythologization of the ideological content, myths about a ruler and a happy future became more actively used in the poetry in the late 1920s. According to Yu. Borev, "in the 20th century there was a desire for moral and political unity and the rise of a ruler, a genius" [Borev, p. 45]. The social system, represented by Z. Freud, meant to elevate the representatives of power and the rest were attributed to those unable to appreciate themselves, those who drifted, who were in a static state: the "ruler - elite - mass" model came to life. Thus, the national ideals of the early 20th century were replaced by the images of Lenin and Stalin that rose as symbols of greatness, justice and maturity, making up a socialist society. Those images became the objects of worship. M. Jalil's poems "V. I. Lenin" (1930), "Unaltynchy udar" (The Sixteenth Strike) (1930), S. Mannur's "Soykemle rasem" (" A Nice Picture") (1933) and others glorified the image of Lenin's struggle. Later works of M. Jalil feautre mythological images of Kirov and Stalin ("Stalinga" ("To Stalin") (1936), "Bez kul kutarabez" ("We Raise Hands") (1937), "Stalin turynda zhyr" ("A Song about Stalin") (1937), as well as others. In the poems by S. Mannur "Tabybyr Allam" ("Allah for Worship") (1937), "Khalyk uly" ("The Son of the People") (1938), the image of the ruler becomes an archetype.

In the poems "V. I. Lenin" (1930), "Unaltynchy udar" ("The Sixteenth Stroke") (1930), as well as in other works, the image of Lenin being the leader of the struggle is glorified, while mythologization uses the images of light, sun and fire. As a special modification of the archetype of a wise old man, Lenin is depicted as a ruler, showing people the way and leading them. Their 
banner is represented as the banner of Lenin. In S. Khakim's poems "Mavzoley yanynda" ("Near the Mausoleum") (1938), "Ike lachyn" ("Two Falcons") (1938), "Skulptor masterskoenda" ("In the Master Sculptor") (1938), "Zhide yashlek dustym" ("My Seven-Year-Old Friend") (1939), "Shagyr oenda" ("In the Poet's House") (1939), "Gomer yana bashlana" ("Life Begins Anew") (1939), "Volodya ant ita" ("Volodya Vows") (1940) and in his other pieces the archetype of Lenin as the image of the wise old man is a part of the ideological framework. When mythologizing, the poet uses the symbolic images of the wind, a high road, a falcon and hot fire in the poems "Mavzoley yanynda" ("Near the Mausoleum") (1938), "Ike lachyn" ("Two Falcons") (1938), "Volodya ant ita" ("Volodya Vows") (1940) to name but a few. Along with this, there was a tendency to mythologize the image of Stalin. In the poem "Ike lachyn" ("Two Falcons") (1938) the process of creating a new way of life is associated with the feeling of joy. Two falcons - Lenin and Stalin - are portrayed as personalities, contributing to the creation of this new life. This thought is often reinforced through the dialogue between the two rulers. The poem interprets the birth of the rulers as a message about the duration and future of the new life, about the happiness of the country.

A reference to oral folk art in poetic thinking led to the revitalization of folklore characters in Tatar poetry. Since the second half of the 1930s, qualitative changes took place in this domain. As regards poetry, pieces were now reflections of popular thinking, classical poetic traditions and lyricism. In our opinion, the continuous use of symbols in the 1930s was due to the strong traditions in Tatar literature. On the one hand, Tatar folklore poetry was interested in folk wisdom, philosophy, a particular way of thinking, on the other hand, it was attracted by the romantic imagery inherent in oral folk art, which laid the foundation of the "folklore style".

The use of images, motifs and symbols from popular poetic ideas led back to the oldest traditions of Tatar poetry. Those references to folklore made it possible to avoid ideological schematism: as can be clearly seen, Tatar poets find folk art with its artistic description of reality to be in close proximity to poetic novelty. Thus, Tatar poetry expanded its boundaries in terms of topics, enriched by graphic means. All this activated the images from folk songs, the images of natural beauty and songs together with colour symbolics. Traditional romantic images such as the morning wind, sunrise, wind, and stars evolved to the level of a poetic code, became key words, recreating the inner world of the lyrical heros, their experiences and desires. This is evident in the following lyrical and lyrical-epic works: M. Jalil's "Ozatu" ("The Seeing Off") (1934), "Sagynu" ("To Ponder") (1936), “Zhir zhilagem” ("My Strawberry") (1937), "Kushalmagach" ("If $\mathrm{He}$ Could Not Order") (1937), "Chishma Zhyry" ("A Spring Song") (1938), “Zhillar" ("Winds") (1938), A. Faizi's "Umyrzaya" (“A Snowdrop") (1933), "Almalarnyn yakty kyzyllygy" ("The Bright Red Colour of Apples") (1937), "Yashlek" ("The Youth") (1938), "Koyma zhyry" ("The Song of the Boat") (1938), "Kyr kazlary" ("Wild Geese") (1940), A. Erikai's "Tan zhillare keber kilermen da ..." ("I will come as the morning wind ...") (1935), "Chishma suy chelteri komesh syman ..." ("Spring water sounds like silver") (1936), "Salkyn chishma chelterap aga ..." ("A cold spring flows sounding....) (1937),"Zangar kulen sagyna-sagyna ..." ("Missing the blue lake.....") (1938), "Min Kitarmen akhry eraklarga ..." ("I seem to be going far.....") (1938), Sh. Mannur's "Gayzhan Babay" ("Gayzhan Babay") (1935), S. Khakim's "Yuksynu" ("Missing") (1938), Kh. Tufan "Ak Kaen" ("A White Birch") (1933); "Louisa" ("Louise") (1929), "Ozatu" ("The Seeing Off") (1933).

In Khasan Tufan's poem "Ozatu" ("The Seeing Off") (1933) this motif is reflected in the images of the guy who is going to the war, and the girl who is seeing him off. The furious and ferocious description of the horse lays the foundation of the motif; the image of a man ready to sacrifice his life for the sake of his homeland goes beyond the socialist way of life established in the country. The soil wrapped in a handkerchief and given to the guy is the symbol of the ardent love and trust of the Motherland in him, the desire to see him return alive and healthy -these details are the manifestations of the romantic spirit permeating the work.

This poetic change is evident in Musa Jalil's poem "Khat tashuchi" ("The Letter Deliveryman"). In this poem, the new life is glorified through the prism of the love story between the brigadier Fairuza, who grows crops, and Timerbulat, who delivers letters. The ideological trend and the storyline show the spiritual development of the individuals, who are building the new life, their patriotism, praising Soviet reality. Moreover, Tatar folk songs help to make their love story more vivid: "bue zifa tal kebek, / joze alsu tan kebek. / joz karachi chulpan kebek, / kuze tatly ball kebek", 
"yalkyn kuzle Fairouzakai kherkemga yakin ide" (Her body is like a slender willow / Her face is like a pink sunrise / She looks like Venus, / Her word is like sweet honey, Fireuzakai with her sparkling eyes is close to everyone, etc.).

In Khasan Tufan's "Ak kaen" ("A White Birch") (1933), which describes the conversation of Khaibulla and a white birch, the images and a dialogue-discourse of a white birch come from folk songs. The motif of struggle in the poem is all about the tragedy of the Civil War, the content is revealed through a rhetorical question and rhetorical appeal: the cause of lyrical hero's mourning is Khaibulla's suicide by hanging himself on a white birch; the image of a white birch renews the traditions of Tatar folk songs and represents sadness, sorrow and grief; the moment when the birch sheds its green leaves enhances the sensual perception of this work.

Folk mythological images of the country and its fate were frequently referred to. As a result, many poems convey the concept of a "country". This novelty can be seen in the poetry of Musa Jalil. The lyrical hero's longing for his native land is described by the phrase "tugan yagim, yakty oem" ("my native land, my bright home"), this longing is expressed through popular mythological images of a swallow, a goldfish and a nimble horse. Flowers, fresh winds, plants covered with morning dew, the planet Venus, a weeping birch these traditional images-details portray the country, fighting for a new life, a great country "where the Tatars live".

Musa Jalil's poem-librettos "Ana" (Mother) (1938), "Altynchech" ("The Golden-Haired Girl") (1940) feature the country that represents the image of the Motherland. Such details as the red mark, the forest, the foliage and the pink flowers seem like an echo of folk tunes. This is clearly evident in the way the image of his native country is depicted. M. Jalil brings a new idea to Tatar poetry: the native country is our Motherland. N. Isanbat's poem "Tugan il" ("The Native Land"), in K. Nadzhmi's "Tugan yortybyz" ("Our Native House"), in G. Kutuy's "Talantlar Vatany" (The Homeland of Talents"), and in A. Alish's "Tugan ilga" ("To the Native Land") convey the same idea. The image of the Mother is mythologized in a series of M. Jalil's poems "Moabit defterleri" ("The Moabit Workbooks"). Here a new chain of symbols can be found: One's home country -its nature -one's native land - the mother. In his lyrical works "Shagyr" ("The Poet") (1942), "Yullar" ("Roads") (1943), "Yash ana" ("A Young Moth- er") (1943) the image of the mother corresponds to the image of the native country and the mankind.

In M. Jalil's poems the motif of heroism is often revealed through folk symbols. Just like all folk tales, the ballad "Ana baireme" ("Mother's Holiday") (1943) tells the story about three sons: two elder sons are killed in the hunt, and the third son returns home as a winner with his "diamond sword". The images of the pigeon and the wind, bringing the news, opening the eyes of the blind mother all serve one purpose, that is, to glorify the struggle for their country. In the ballad "Sandugach ham Chishma" ("The Nightingale and the Spring") (1942) allegorical imagery is used to promote the idea of sacrifices for the sake of the country in the war for its liberation; the beauty of nature serves to enhance the ugliness of death. In the ballad "Kyzyl romashka" ("The Red Chamomile") (1942) the chamomile personifies outstanding heroism, devotion to one's country and heroic firmness.

This change of quality is associated with the motif of struggle, expressed with the help of two images: a valiant young man-wrestler - a Tatar young man. The described images, whose origins and roots go deep into folklore, take the poetry of the 1920s beyond the normative framework of social realism. In M. Jalil's poem "Batyr eget turynda zhyr" ("The Song about a Brave Guy") (1936), in Kh. Tufan's “Ak kaen” (“A White Birch”) (1933), in F. Karim's "Yashen Yaktysy" ("The Light of Lightning") (1932) the image of a bold young man is enriched with mythological tones using such details as a grey horse, a sharp sword and a sparkle of lightning; he becomes a brave soldier from Tatar folk fairy tales.

The image of the archetypal hero-fighter from M. Jalil's works demonstrates his qualities of a lionheart who protects his homeland, of a loyal soldier and a hero-poet. The lyrical hero from the poem "Shagyr" ("A Poet") (1942) acts as a superman, who defeats the hurricane with his creative work. In the poems "Bula kaichak" ("Sometimes It Happens") (1943), "Zhyrlarym" ("My Songs") (1943) we see the hero as a brave warrior, who fights for the independence of his country, engaging other people into the battle with his songs and giving his life, work and death for the independence of his state.

In Tatar wartime poetry folklore images are used for several purposes: to depict the lyrical hero's feelings in all their manifestations, to convey philosophical thoughts and the author's positions through symbolic and allegorical images and, finally, to convey the feeling of love and longing for 
the Motherland to its readers. In F. Karim's poem "Bezde yazdyr" ("It's Spring There") (1942) the concepts of "war and peace" are contrasted by two different worlds: the land occupied by fascists and the peaceful areas of the motherland. In general, the juxtaposition of war and beauty is F. Karim's most favorite and frequently used device. Written in the form of a monologue, this poem features the image of spring, which is the symbol of hope, renewal and bright future. Through this image, F. Karim expresses his general opinion and philosophy: fascism destroys not only humanity but also the beauty and the very foundation of nature. In the poem "Sibali da sibali" (It Keeps Pouring) (1942) the image of autumn rain symbolizes the feelings of the suffering lyrical hero, who lost his best friend and comrade. The author's impersonations, his tragic pathos, the use of repetitions, figurative metaphors and epithets - all these reinforce our artistic perception of the lyrical hero's feelings and make the tragic motif more acute.

At the same time, by drawing on folklore and its images [Khalit, p. 139] the poets tried to avoid ideological emphasis. From the second half of the 1930s, they began to more deeply reflect on the changes in the world and society; their changing attitudes towards ideology led to the enrichment of national poetry with new techniques. The public opinion developed based on symbolic images, the focus was shifted to the description of the protagonist's inner world. According to L. A. Kolobaeva, this phenomenon is called "a tendency of predicting and evaluating the social development" [Kolobaeva, 1991, p. 216]. As a rule, in these conditions Aesopian language and the device of hidden content are used particularly often. Regardless of strict political rules the symbols of folklore are still used to express the authors' negative attitudes to the ideology and manifest their assessments of the socio-political development.

The changes in the poets' worldview in relation to the original ideology began to manifest themselves in the content of their works. The civic content of poetry aggravated their critical attitude to the Soviet system and to the representatives of power, deepened their understanding of current problems, the fate of their nation, morality and traditions of their people. Their assessments of political issues appeared in the works, related to the historical epoch and social situation, which was most often done through hidden content, allegories, Aesopian language and symbolization.

This phenomenon can be explained from a sociological point of view. According to $\mathrm{L}$.
A. Kolobaeva, symbols primarily appear as a forecast for the future of society, the world and the nation, these symbols are amplified, especially in the era of changes in literature, in socio-philosophical and political ideas, under spiritual and political pressure [Kolobaeva, 1991, p. 216] because at these times the principles of a secret language and hidden content get activated. Tatar poetry of the 1930s is a good example of it, as it demonstrates the functions of symbols in the poetry of that period: the writers enrich their works with political content, focusing on the ideology of the subjective content, and the assessment of the new order of things. This new approach affected the change in the conception of the personality. The new content described the new status of the lyrical hero, striving to understand the place and the role of his people in this world.

$\mathrm{Kh}$. Taktash is considered to be the first to reflect this change in his works. In his poems "Ertyk Burek" ("The Torn Hat") (1927), "Bolay gadi zhyr gyna ..." ("Just a Simple Song...") (1928), “Ak chechekler" ("White Flowers") (1929), "Ay kebek bez ozak yashamibez" ("We Do Not Live as Long as the Moon") (1928) the lyrical heroes start thinking about the falsity of certain ideological statements. Such symbolic images as wind and frost are used in Taktash's works.

In A. Fayzi's poems "Umyrzaya" ("The Snowdrop") (1933), "Yashlek" ("Youth") (1938), "Kuz" ("Autumn") (1939), "Yafrak khem chiklavek" (“A Leaf and a Nut") (1939), F. Karim's "Ellar uta, eragaya bara" ("Years Are Running By, Flying Away") (1940), "Kyr kazy" (“A Wild Goose”) (1941), "Kozge yangyrly ton..." ("One Autumn Rainy Night") (1939) the focus is on the details of the symbolic image that has a double meaning; they evaluate people, their spiritual beauty and their place in society according to the benefits they bring to the nation. Their lyrical heroes talk about the mistakes, made in the process of creating a new way of life, while metaphors, symbols and epithets are used to assess and evaluate the political course.

In Kh. Tufan's poems "Suzsez gena" ("Without Words") (1937), "A yoldyzlar dashmi" ("The Stars Are Silent") (1937) the lyrical hero claims that politics and ideology are false. The poem "Yoldyzlar dashmi" ("The Stars Are Silent") (1937) is remarkable for its opposition "spiritual freedom -ideological eclipse"; here the lyrical hero discusses making mistakes in the new life, the epithet "in kaderle ere irlarne domge soyragan" ("the most necessary men are drawn into the darkness") describes the mainstream of political life. The 
fragment "vaemsyz zhilnen kerep, daverne, kibannarne tuzdyru" ("the careless wind destroyed the era, and the stacks") is the reason for worrying. The author gets his opinion across through the image of the careless wind, personifying Soviet ideology; intellectuals can be discerned behind the image of a stacked ceiling; the chaff symbolizes a flatterer, a person that has no opinion of their own. The lyrical hero suffers from not being able to change reality and appeals to the stars in search of solace, but their silence promises no hope. In this poem the lyrical hero is perceived as a fighter who disagrees with existing rules and attempts to change them.

The poem "Agyla da bolyt agyla" ("The Cloud Drifts On") (1951) portrays the lyrical hero who is forced to leave his homeland and is indifferent to the environment where society and people fail to notice the changes that have led to the emergence of a personality cult. The cloud represents the fate and the life of the lyrical hero, which are transformed into the symbols of freedom and bondage. The repetition of the rhetorical question "What shall I say to my relatives?" and the word combination "agyla da agyla" (flows and flows) increase the level of anxiety; even the intonation changes and the ironic assessment of the protagonist's lifeline is focused on the same goal.

The poem "Ilda nilar bar ikan?" ("What Is There in the Country?") (1944) describes the suffering of a person separated from his family, the person in isolation, who worries about the fate of the country that has rejected him. The image of the lyrical hero serves to share the author's opinion about the events with readers. The lyrical hero is lonely and uncertain, his dreams are ruined, thus the author dwells on the idea of the tragedy experienced by the country and the people: Ilda nilar bar ikan: / Yullar zangar kar mikan? / Havadagy alsu shaula / Pozhar mikan, tan mikan? / Ilda nilar bar mikan? (What is there in the country: / Perhaps the roads of blue snow? / Pink shadows in the sky / Could it be fire or dawn? / What is there in the country?) [Tufan, p. 233]. The images of blue snow, fire and dawn, used in the first stanza of the poem, are repeated and become symbolic: blue snow and dawn signify the lyrical hero's hope for a brighter future, whereas the fire symbolizes the bloody events in the country. In several poems, including "Avyrgan minutlarda" ("At the Moments of Illness") (1942) and "Kayat" ("Hayat") (1942) the author points out the inhumanity of the new ideology and uses Aesopian language to describe the socio-political situation.
Thus, the analysis of the system of symbols in Tatar poetry of the 1920 s and 1950 s allows us to gain better understanding of numerous processes that occur in verbal art. This demonstrates that as Tatar literature evolved, it followed its own national path, different from that of other literatures. The use of oral folk art in verbal art, the use of traditional images of Tatar literature to personify ideological and mythological images made it possible to get round political restrictions. As a result of literary interactions with folklore, Tatar poetry became enriched with personal emotionality and national spirit. At the same time, the activation of hidden content deepened the subjective layer in poetry, allowing writers to turn to existing traditions.

With time these motifs and techniques from verbal art and images of oral folk art in poetic reasoning lost their genetic authenticity and acquired sociological and sociopolitical content. At the same time, the fact that they were used meant that literary traditions were carried on, developed and made more complex, while classical foundations and values of verbal art were preserved. Thus, in terms of the literary development, a platform was being prepared for the third "explosion", which would occur in the 1960s, and for literary criticism, which would emerge; those changes in the deeper layers of verbal art were the testimony to literary renewal.

\section{References}

Balashova, Yu. B. (2016). Russkaia literatura XX veka: istoriia, khudozhestvennaia ideologiia, poetika: uchebnoe posobie [Russian Literature of the Twentieth Century: History, Artistic Ideology, Poetics: A Textbook]. 124 p. St. Petersburg, Vyssh. shk. zhurn. i mas. Kommunikatsii. (In Russian)

Bertel's, A. Ye. (1997). Khudozhestvennyi obraz v iskusstve Irana IX-XV vekov (Slovo, izobrazhenie) [Artistic Image in Iranian Art of the $9^{\text {th }}-15^{\text {th }}$ Centuries (Word, Image)]. 422 p. Moscow, izdatel'skaia firma "Vostochnaia literatura" RAN. (In Russian)

Borev, Yu. B. (2001). Osobennosti literatury v XX veke. Teoriia literatury [Features of Literature in the $20^{\text {th }}$ Century. Theory of Literature]. T. 4. Literaturnyi protsess. Pp. 456 - 469. Moscow, IMLI RAN. (In Russian)

Burnash, F. (1978). Odəbiiat həm səngat' turynda [On Literature and Art]. 238 p. Kazan, Tatar. kit. nəshr. (InTatar)

Galimullin, F. G. (1998). Estetika həm sotsiologizm: 20-30 nchy yellar tatar adəbiyatynda estetika kanunnarynyң həm sotsiologizm taləpləreneң Yzara menəsəbəte [Aesthetics and Sociology: Relationships of Aesthetic Canons and Requirements of Sociol- 
ogy in Tatar Literature in the 1920s-1930s]. 223 p. Kazan, Məgarif. (In Russian)

Gacheva, A. G. (2003). Filosofskii kontekst russkoi literatury 1920 - 1930-kh godov [The Philosophical Context of Russian Literature in the 1920s - 1930s]. 400 p. Moscow, IMLI RAN. (In Russian)

Golubkov, M. M. (1992). Utrachennye al'ternativy: Formirovanie monisticheskoi kontseptsii sovetskoi literatury 20-30-ye gody [Lost Alternatives: The Formation of a Monistic Concept in Soviet Literature in the 1920s - 1930s]. 202 p. Moscow, Nasledie. (In Russian)

Golubkov, M. M. (2001). Russkaia literatura XX veka: Posle raskola [Russian Literature of the Twentieth Century: After Splitting]. 267 p. Moscow, Aspekt Press. (In Russian)

Günther, Kh. (2000). Totalitarnoe gosudarstvo kak sintez iskusstv. Sotsrealisticheskii kanon: sb. statei [Totalitarian State as a Synthesis of Arts. A Socialist Realistic Canon: Sat. Articles]. Pod obshch. red. Kh. Gyuntera i Ye. Dobrenko. Pp. 7. - 15. St. Petersburg, Akademicheskii proekt. (In Russian)

Жəlil, M. (1976). Altynchach [The Golden-Haired Girl]. Osərlər, 4 tomda. T. 2, pp. 251 - 322. Kazan, Tatar. kit. nəshr. (In Tatar)

Ibrahimov, G. (1978). Tatar adabiiaty [Tatar Literature]. (2) (Yellyk khisap urynynda). Osərlər: 8 tomda. T. 5, pp. $404-419$. Kazan, Tatar. kit. nəshr. (In Tatar)

Iusupova, N. M. (2016). Fol'klornye simvoly kak istochnik simvolizatsii $u$ tatar (na materiale ornitomorfnoi i tsvetovoi simvoliki) [Folk Symbols as a Source of Symbolizm in Tatar Culture (based on ornithomorphic and color symbolism)]. Vestnik Ryazanskogo gosudarstvennogo universiteta imeni S. A. Iesenina. No. 4 (53), pp. 138-145. (In Russian)

Khabutdinova, M. M. (1998). Problema lichnosti $v$ tvorchestve Kh. Taktasha: dis. ... kand. filol. nauk [The Problem of Personality in the Works of $\mathrm{H}$. Taktash:Ph.D. Thesis]. Kazan', 181 p. (In Russian)

Khalit, G. M. (1980). Poeziia derzanii [The Poetry of Daring]. 160 p. Kazan', Tat. kn. izd-vo. (In Russian)

Khalizev, V. Ye. (2000). Teoriia literatury: uchebnoe posobie [Theory of Literature: A Textbook]. 398 p. Moscow, Vyssh. shk. (In Russian)

Kling, O. A. (2010). Vliianie simvolizma na postsimvolistskuiu poeziiu v Rossii 1910-kh godov: problemy poetiki [The Influence of Symbolism on PostSymbolist Poetry in Russia of the 1910s: Problems of Poetics]. 356 p. Moscow, Dom-muzei Mariny Tsvetaevoi. (In Russian)
Kolobaeva, L. A. (1991). Simvol kak khranitel' $i$ vozmutitel' klassicheskikh traditsiy (obraz Don-Zhuana $v$ russkoy literature kontsa XIX - nachala XX veka) [The Symbol as the Keeper and Breaker of Classical Traditions (the Image of Don-Juan in Russian Literature of the late 19th - Early 20th Century)]. Klassika i sovremennost', pp. 207 - 216. Moscow, izd-vo MGU. (In Russian)

Kolobaeva, L. A. (2000). Russkii simvolizm [Russian Symbolism]. 296 p. Moscow, izd-vo MGU. (In Russian)

Mesəgyit', F. (1937). Redaktsiiagə khat. Tatar opera studiiase turynda [A Letter to the Editorial Board. On Tatar Opera Studio]. Kyzyl Tatarstan. 21 avgust. (In Tatar)

Nig"məti, G. (1931). Utyz berenche yelga kerganda [On the Eve of the Thirty-First Year]. Iayalif. No 1, pp. 36 - 41. (In Tatar)

Nigmatullina, Yu.G. (1997). Tipy kul'tur $i$ tsivilizatsii $v$ istoricheskom razvitii tatarskoi $i$ russkoi literature [Types of Cultures and Civilizations in the Historical Development of the Tatar and Russian Literatures]. 192 p. Kazan', izd-vo "Fen” AN RT. (In Russian)

Sarukhanian, A. P. (2010). K sootnosheniiu poniatii "modernism" $i$ "avangardizm" [On the Relationship between the Concepts of "Modernism" and "Avantgarde"]. Avangard v kul'ture XX veka (1900-1930 gg.). Teoriia. Istoriia. Poetika, v 2 kn. Kn.1, pp. 9 - 33. Moscow, IMLI RAN. (In Russian)

Semenova, S. G. (2001). Russkaia poeziia i proza 1920 - 1930-kh godov. Poetika - Videniye mira Filosofiya [Russian Poetry and Prose of the 1920s and 1930s. Poetics - Vision of the World - Philosophy]. 590 p. Moscow, IMLI RAN, "Naslediye”. (In Russian)

Stetsenko, Ye. A. (2009). Kontsepty khaosa $i$ poriadka $v$ literature SSHA. Ot dikhotomicheskoi $k$ sinergeticheskoi kartine mira [Concepts of Chaos and Order in US Literature. From the Dichotomous to Synergistic Picture of the World]. 264 p. Moscow, IMLI RAN. (In Russian)

Taktash, h. (1980). Osarlar: 3 tomda [Works in Three Volumes]. T.1, 352 p. Kazan, Tatar. kit. nəshr. (In Tatar)

Tufan, Kh. (2007). Osarlar [ Works]. 5 tomda. T. 1, 479 p. Kazan, Tatar. kit. nəshr. (In Tatar)

Zagidullina, D. F. (2013). Modernizm v tatarskoi literature pervoi treti XX veka [Modernism in Tatar Literature of the Early Twentieth Century]. 207 p. Kazan', Tat. kn. izd-vo. (In Russian) 


\title{
1920-1950 ЕЛЛАР ТАТАР ПОЭЗИЯСЕНДӘ СИМВОЛЛАР: ТӨРЛӘРЕ, ФУНКЦИЯСЕ ҺӘМ НОМИНАТИВ МӘГЬНӘЛӘРЕ
}

\author{
Нурфия Марс кызы Юсупова, \\ Казан федераль университеты, \\ Россия, 420008, Казан ш., Кремль ур., 18 нче йорт, \\ faikovich@mail.ru.
}

\begin{abstract}
Мәкаләдә 1920-1950 еллар татар шигъриятендәге символлар системасы тикшерелә. h. Такташ, М. Гафури, Х. Туфан, М. Жәлил, К. Нәжми, Ш. Маннур, С. Хәким, Ә.Фәйзи, Ф. Кәрим h.б.ларның әдәби әсәрләре гыйльми эзләнүләрнең объекты булып тора. Тикшеренүләр символлаштыру процессының түбәндәге үзенчәлекләрен аерып чыгарырга мөмкинлек бирде. Беренчедән, әдәби барышта үзгәрешләр башланса да, поэтик яктан шигъри сүз үткән дәверләр белән бәйләнешен дәвам итә. Мифологик сюжет һәм мифологик образлар символ статусында кулланылып, автор яшәгән чорны бәяләүгә юнәлтелә, шуңа бәйле төстә символлаштыру барышында эчке әдәби синтез алымы кулланыла. Икенчедән, сүз сәнгатенә карашның үзгәреше, аны ижтимагый фикернең бер канаты итеп күтәрү идеологик эчтәлекле символларның әдәби мәйданга чыгуына китерә. Еш кына моңа кадәр традицион мәгънәдә калыплашкан, милли шигърият өчен «үз» булып әверелгән символлар да өр-яңа идеологик эчтәлек белән байый. Өченчедән, халык авыз ижатыннан килгән образларны, символларны файдалану татар шигъриятенең борынгыдан килгән традицияләрен тергезүгә китерә. Фольклор катламына мөрәжәгать идеологик схематизмны атлап чыгарга мөмкинлек бирә: татар шагыйрьләре поэтик яңарышны, чынбарлыкны сәнгатьчә тасвирлауда якынлыкны шунда таба. Дүртенчедән, халык авыз ижатын файдалану, фольклордан үсеп чыккан символлар, читләтеп әйтүнең һәм идеологик басымнан качуның бер чарасы кебек аңланылып, алар ярдәмендә жәмгыятькә житлеккән караш сизелә башлый. Совет системасына, хакимият вәкилләренә тәнкыйди караш, яңа тормышның көнүзәк проблемаларын яшәеш, милләт язмышы, халык әхлагы һәм традицияләре нокталарыннан күздән кичерү 1920-1950 еллар поэзиясенең гражданлык эчтәлеген тирәнәйтә. Күренә ки, сүз сәнгатенең символик сурәтләр катламындагы үзгәрешләр, бер яктан, яңа ижтимагый һәм мәдәни шартларда поэтик эзләнүләр белән билгеләнсә, икенче яктан, элгәрге һәм XX йөз башы казанышларын дәвам итү, халык авыз ижатыннан үстерелә килгән символларга мөрәжәгать аша классик традицияләргә кайту белән характерлана.
\end{abstract}

Төп төшенчәләр: татар шигърияте, символ, трансформация, образ, шәхес концепциясе, функция, номинатив мәгънә.

Тикшеренү РФТФ һәм Татарстан Республикасы Хөкүмәте гранты кысаларында башкарылды (18-412-160008 нче номерлы гыйльми проект).

1920-1950 еллар татар поэзиясе тарихында үзенчәлекле әдәби-тарихи чор буларак тарихка кереп кала. Ул үз эчендә ике этапны берләштерә: егерменче-утызынчы еллар, сугыш hәм сугыштан соңгы еллар шигърияте. Әлеге ике баскыч, идея-эстетик үзенчәлекләр жәһәтеннән бербөтенне тәшкил итеп, бер-берсенең дәвамы кебек үсә-үзгәрә. Бу бүленеш символлар системасы өчен дә актуаль булып кала, анда барган үзгәрешләр социомәдәни һәм әдәбиэстетик шартларның, фәлсәфи күзаллауларның трансформациясенә барып тоташа. Мондый шартларда кешелек жәмгыятендә һәм аңында барган үзгәрешләргә гаять сизгер әдәби сүз ачык үсеш сукмакларын һәм логик тәртибен югалткан тормыш-чынбарлыкны яктыртуның яңа юлларын эзли башлый [Стеценко, с. 106]. Бу яктан 1920-1950 елларда барган эзләнүләрне, әдәбият белгеченең фикерен дәвам итеп, ХX йөз башы идеалларының «жимерелүе» дип бәяләргә дә мөмкин булыр иде.

M.M. Голубков, 1920-1930 еллар рус әдәбиятында ике агымның параллель үсүен билгели: бер яктан, эстетик кануннар актуальлеген югалтмый, икенче яктан, идеологик эчтәлекнең көчәюе, аңа хас сурәтләү чараларның мәйданга чыгуы күзәтелә [Голубков, 1992, с. 5]. Нәтижәдә бер әдәбият чикләрендә ике агым, ике «мәдәният» формалаша: алар иске белән яңаның көрәше төсен ала [Голубков, 2001, с. 49]. Шушы шартларда сүз сәнгате, «алдагы дәвердә урын алган модерн традицияләренең һәм социаль үзгәрешләр чорындагы көчле энергиянең бергә 
үрелүе нәтижәсендә, үтә хәрәкәтчән, тиз үзгәрүчән, пассионар сценарий белән үсә» [Балашова, с. 10]. Бу үзенчәлекләр татар әдәби жирлеге мисалында да актуаль яңгырый, әмма бу үзгәрешләр үзенчә, үзгә төсмерләрдә бара.

1920-1950 еллар татар шигъриятендә символлар системасы идеологик эчтәлекле шартлы образларның киң мәйданга чыгуы һәм $\mathrm{XX}$ йөз башы классик традицияләрен дәвам итү, социалистик реализм агымының схематик чикләреннән чыгу, халык авыз ижатыннан үстерелә килгән символларга мөрәжәгать аша классик традицияләргә кайту белән билгеләнә. Шуңа бәйле бу чордагы символлар системасы үсешен бәяләгәндә, Ю.Б. Боревның «капмакаршы процессларның очрашуы» [Борев, с. 463] теориясен кабатларга мөмкин: символлар системасында яңа, идеологик һәм классик, эстетик кануннар, алымнар, номинатив мәгънә, функцияләр бергә кушылып, үрелеп китә. Рус әдәбиятында классик, фольклор традицияләренең үсешен С.Г. Семенова «авыл поэзиясе» вәкилләре ижаты белән бәйләп карый [Семенова, с. 41]. Рус әдәбиятында «авыл поэзиясе» hәм пролетар әдәбият ике канатны тәшкил итсә, татар жирлегендә алар үзара үрелеп китә. Бер үк әдип ижатында идеологик hәм фольклор символлары, классик традицияләр параллель үсә-үзгәрә.

Чор әдәбиятында символларның берничә төре актив кулланылышка кереп китә: XX йөз башы классик традицияләренең дәвам ителүен дәлилләп, мифологик символлар кулланыла; идеологик эчтәлекле символлар формалаша; романтик шигърият традицияләрен яңартып, халык авыз ижаты символлары тергезелә һәм алар өр-яңа - «идеологик фикерләрне жимерү» функциясендә файдаланыла башлый.

Символистик һәм романтик әсәрләрдә мифларга мөрәжәгать итү, мифологик символларны актив куллану (h. Такташ «Күктән сөрелгәннәр», 1918, «Жир уллары трагедиясе», 1923; М. Жәлил «Кабил һәм Һабил», 1923, «Яңа тарихы әнбия», 1923; М. Гафури «Күк жырлары», 1923 h.б.) эчтәлек ягыннан тирән, төрлечә укылу вариантына ия, символлар бирелеше ягыннан катлаулы әсәрләр язылуны дәвам итә, алар гасыр башы фәлсәфи әдәбияты традицияләрен үстерә. Мондый әсәрләрдә фольклор, миф сюжетлары һәм образлары автор яшәгән чорны бәяләүгә юнәлтелә, шуңа бәйле төстә символлаштыру барышында эчке әдәби синтез алымы кулланыла. Ф. Бурнаш 1929 елда язган мәкаләсендә бу күренешне «Дәрдемәнд мәктәбе» йогынтысы белән аңлата, әлеге үзенчәлекнең Такташ шигъриятеннән тыш, Ә. Сәгыйди, Ченәкәй, К. Нәжминең беренче шигырьләрендә дә чагылыш табуын шәрехли [Бурнаш, б. 236].

Мәсәлән, h. Такташ 1918 елның августында «Күктән сөрелгәннәр» исемле әсәрен ижат итә, әмма ул 1923 елда гына дөнья күрә. Мифологиядән алынган сюжетта, Алла хөкемен жиренә житкереп, гел кеше суеп йөргән Газраил гаделлек, кешелек яклы фәрештә кызны юк итәргә әмер ала. Кызны күргәч, Газраил аңа гашыйк була һәм Алла хөкемен үтәүдән баш тарта. Алла, моңа үч итеп, кызны ташка әйләндерә. Алланың явызлыгына тәмам күзе ачылган Газраил аңа каршы бунт күтәрә; аның явыз гамәлләрен фаш итеп, ялкынлы сүзләр сөйли, үтерү эшен ташлап, адәм улларына хаклык сөйләү юлына баса. Шагыйрь символик яссылыкта чорга аваздаш фикерләрне ассызыклый: Газраил һәм Алла образлары аша кешенең инкыйлаб биргән мөмкинлекләрдән файдаланып, искелеккә каршы бунт күтәрүен, рухи алмашынуын, гаделлекне юк итәргә, кеше аңын каплап тотарга омтылган көчләргә каршылыгын житкерә.

h.Такташның «Таң кызы» (1921) шигыре дә мифологик традицияләргә таянып языла. Көнчыгыш мифологик символлары лирик геройның таң кызына булган романтик мәхәббәтен символлаштырып килә. Ут символы, кызыл чәчәк образлары да шартлы төстә мәхәббәтне илаһилаштыруга хезмәт итә: Пәри кызыл! Ник чыктыцц да юлларымиа, / Утльл кызыл гөлләр тотыл кулларыңа, / Гөлләрецне ыргытыл, бер елмайдың да /Ник ямерендең, төренеп таң нурларына? [Такташ, б. 109].

$\mathrm{XX}$ йөз башы романтик традицияләрен дәвам итеп, шагыйрь Пәри кызына мәхәббәте хакында сөйли. Билгеле булганча, Пәри фарсы hәм иран мифологиясендә «вакытлыча жәннәттән куылган һәм кешеләрне женнәр йогынтысыннан саклаучы» символ булып йөри [Бертельс, с. 142-144]. XX йөз башы әдипләре кыз образын «матурлык, ихласлык» [Колобаева, 2000, с. 157] мәгънәләрендә актуальләштереп жибәрә. Пәри образын тасвирлаганда кулланылган эпитет, алымнар шигырь тукымасында аның ике яклы сурәтләнүенә басым ясый. Беренчедән, ул илаһи мәхәббәт кебек укыла, икенчедән, гади жир кызына (Гөл) булган хисләр булып кабул ителә. Рус символистлары үрнәгендә шигырь- 
дәге кыз образы да лирик герой өчен кул житмәс идеал, аны акылдан шашу дәрәжәсенә житкергән, эгоистлык хисен югалтырга мәжбүр иткән изге мәхәббәт чыганагы итеп сурәтләнә. Бу яктан ул Вл. Соловьевның мәхәббәт фәлсәфәсен дәвам итә. Соңрак Таң кызы образы шушы ук мәгьнә калыбында һәм аваздаш функциядә $\mathrm{h}$. Такташның «Урман кызы» (1922), М. Жәлилнең «Жил» (1937) шигырьләрендә дә яңгыраш таба.

h. Такташның яңа тип гыйсъянчы, көрәшче шәхес концепциясен гәүдәләндергән [Хабутдинова, с. 12] «Жир уллары трагедиясе» (1921) дә мифологик сюжетны гына түгел, ә барлык образларны да символ югарылыгына күтәрә: алар нинди дә булса идеяне символлаштыралар. «Символизм көчәергә, тирәнәергә уйлый. «Жир уллары» мәжмугасендә моның беренче тәжрибәсе бирелде. Гәзитләрдә, журналларда бу дәвам итә, бу агымның көчле, үткен талантлы шагыйре Такташев безнең шигъри дөньябызда аерым ялгыз бер урында торадыр» [Ибраһимов, б. 412], - дип яза Г.Ибраһимов 1924 елда. Бу абстракт идеяләрнең бер төркеме канунчылык, тәкъдиргә буйсыну кирәклекне күрсәтсәләр, икенче төркем шуңа каршы көрәшне, шәхси ирек проблемасын күтәрә. Әлеге күренеш Yз чорында h.Такташның Г.Нигъмәти тарафыннан тәнкыйтьләнүенә дә сәбәп була: «Бу вакыт Такташ иске әдәбиятның нык тәэсирендә, - дип яза ул. - Аңарда мистиклык үзенең йогынтысын күрсәтеп тора... анда «канун Жәбраил» аерым символик сурәт итеп алына» [Нигъмәти, б. 73].

Әсәр структурасында Идея-Газазил азатлык hәм бәхет өчен көрәш символы булып яңгырый. Моннан тыш ул шагыйрь өчен яңа, әлегә кадәр күрелмәгән яшәеш моделе булып та укылып, ул каргалган илгә каршы куела һәм матур, якты сарайлар, чәчәкле, якты болыннар, азат жилләр образлары ярдәмендә яктыртыла. Шушы яссылыкта әсәр инкыйлабый идеяләрне укучыга житкерә, революцион күтәрелешне азатлык һәм бәхеткә илтүче юл дип раслый:

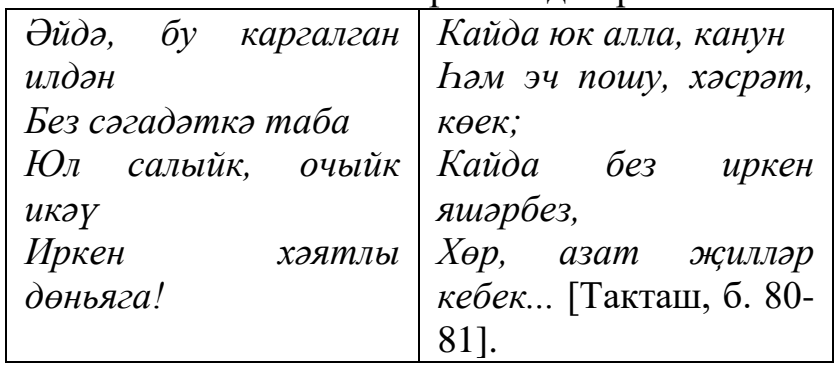

Әлеге образлар башка мәгънәви яссылыкта уку мөмкинлегенә дә ия. Әдәбият белгечләре
«Жир уллары трагедиясе»нең Байронның «Каин» поэмасы тәэсирендә язылуын күрсәтә [Халит, с. 21]. Яшь шагыйрьләр инкыйлабый идеяләр белән гыйсъянчылык фикерләре арасында уртаклык күрә, hәр әдип үзен «жир тормышын, яшәеш кагыйдәләрен үзгәртергә сәләтле пәйгамбәр-көрәшче итеп тоя» [Загидуллина, с. 177]. Бу яссылыкта Адәм белән һава кешелек символы булып укыла, Каф тавы кеше күңелендәге, тормышындагы ике якның - яхшылык һәм явызлыкның, куркаклык hәм батырлыкның - чиген символлаштыра. Идея-Газазил акыл һәм азатлык символы, ә Газраил (Канун) куркаклык һәм коллык билгесе итеп сурәтләнә. Шулар аша автор үз идеясен житкерә: кешелекнең бәхетсезлеге аның hәртөрле кануннарга буйсынып яшәве һәм куркаклыгының нәтижәсе булса, ә бәхеткә юл Y3 күңелеңдәге коллык һәм куркаклыкны жиңүдән башлана.

Халык авыз ижаты сюжетын һәм образларын символ югарылыгында файдалану тенденциясе М.Жәлилнең Жик-мәргән хакындагы мифологик сюжетка нигезләнгән «Алтынчәч» (1940) либреттосында да күренә. 1937 елда ул шуңа мөнәсәбәттә заманның «курчак идеологлары» тарафыннан тәнкыйтькә дә дучар була. Вульгар социологизм тарафдары Ф. Мөсәгыйть «Кызыл Татарстан» газетасында басылган «Редакциягә хат. Татар опера студиясе турында» исемле мәкаләсендә М.Жәлил әсәрләрен «буржуаз караш калдыклары» [Мөсәгыйть, 1937] дип гаепли, «Балыкчы кыз» hәм «Алтынчәч»кә тискәре бәя бирә. «Алтынчәч»тә көчле рухлы, язмышның сынауларына да бирешмәгән, бетүгә хөкем ителгәннән соң да югалмаган Тугзак ана татар халкының символик гәүдәләнеше, башбирмәс образы булып аңлашыла: Бетермәкче идең ыругымны, / Менә - үзем, мена - улларым. / Халык мәнце үлми [Жәлил, б. 319].

Жик-мәргән - аның лаеклы дәвамы булса, Алтынчәч азатлык символына әверелә. Ул азатлыкны, бәхетне ярату. Алтынчәч Жикнең бәхете, өмете, азатлыгы. Димәк, ул халыкның да бәхете, өмете һәм азатлыгы. Татар халкының азатлык, бәйсезлек өчен көрәшен гәүдәләндерү аша субъектив эчтәлектә Жәлил халыкның шул чордагы яшәешен чагылдыра, әсәрне шагыйрь туган халкын Тугзак ана кебек батыр булырга чакыру идеясе белән баета. 
Шуның белән янәшәдә татар шигъриятендә якты киләчәккә ышаныч, илдәге сәяси вәзгыятькә табыну, коммунистик жәмгыять төзү идеяләре калку чагылыш таба. Ф. Галимуллин фикеренчә, егерменче еллар ахырына инде әдәбият тулысынча диярлек сәясәт һәм идеология максатларына хезмәт итә башлый [Галимуллин, б. 44]. Рус әдәбияты үрнәгендә шигъри сүз чынбарлыкны эстетик чагылдыру, дәүләти мифларны киң катлам укучыга ирештеру [Гюнтер, с. 7], идеологик лозунгларны поэтик телдә житкерү [Гачева, с. 149] мәйданына әверелә. 1920 еллардан семантик-синтаксик мәдәният төренең активлашуы [Нигматуллина, с. 170] да әдәби мәйданда идеологик эчтәлекле символларның актуальләшүенә китерә.

Инкыйлаб китергән яңа чынбарлыкны күтәренке хисләр ярдәмендә жырлау шигърияттә публицистик-агитация, сатириккомик шигырьләрне алга чыгара, таң, кояш, көн символлары инкыйлабый эчтәлек ала. Бу традицион образлар еш кына үзләренең калыплашкан мәгънәләреннән ераклашкан вазифада да кулланыла. Егерменче елларның икенче яртысыннан сүз сәнгате аларны социалистик инкыйлабтан соң тулаем искелектән баш тарту, үзгә дөнья, яңа тормыш кору, коммунизмга омтылу сәясәтен житкерүдә киң файдалана башлый. Аларның эчтәлегендә инкыйлаб тудырган жиңү пафосы, патетика, романтик рух өстенлек итә.

Галимнәр XX гасыр сәнгатен мифлаштыру сәнгате дип тә атыйлар. «Фундаменталь мәдәният XX гасырда тоталь мифлаштырыла, миф әдәби, фәлсәфи, идеологик, хәтта сәяси корылмаларның беренчел элементына әйләнә» [Хализев, с. 8]. Чор әдәбиятын иңләп барган идеологик мотивлар пәйда була: якты киләчәккә бару, изге көрәш юлында корбан булу, көрәш, туган илнең матурлыгы һәм хезмәт. Әлеге мотивлар ил, байрак (әләм), көрәшче, дошман кебек бер төркем яңа идеологик эчтәлекле мифологик образсимволларны мәйданга чыгара. Шагыйрьләр тарихи барышның асылын гәүдәләндерә торган образларны сайлыйлар, алар аша иске тормыш белән көннән-көн ныгып килгән социалистик тәртипләр арасындагы каршылыкка эмоциональ мөнәсәбәтләрен белдерәләр. Шушы фонда халык күңеленә тәэсир итәрлек шигъри фикерне тудыруга ике төс, ике тон катнаша; кызыл һәм кара, бәйрәм һәм үткәндәге михнәтле тормыш, кызыл каһарманнар һәм ерткыч дошманнар, яңага мәхәббәт һәм үткәнгә нәфрәт.

Идеологик символлар сан ягыннан футуристик hәм имажинистик тәжрибәләр исәбенә дә байый. О.А. Клинг, 1910 елларда Россиядә символизм һәм постсимволизм агымнарының үсеш-үзгәрешен өйрәнеп, шундый нәтижәгә килә: «үткәндәге модернистик тәжрибәләр, шул исәптән символизм белән бәйләнешләрен дә кискен өзү юлын сайлаган футуризм асылда символистик традицияләрдән үсеп китә» [Клинг, с. 40]. Әдәбият галимнәре фикеренчә, футуризм символизм поэтикасының дәвамы булып мәйданга чыга [Саруханян, с 29], футурист шагыйрьләр ижатында, трансформацияләнгән хәлдә булса да, символистик идеаллар дәвам итә [Гачева, с. 14], бу күренеш исә символларның номинатив кырын яңа мәгънә бөтенлекләре белән баету мөмкинлеген бирә.

Бу фикерләр татар шигъриятендә Х. Туфан, К. Нәжми, М. Жәлил әсәрләре мисалында дәлилләнә. Мәсәлән, яшь шагыйрь Х. Туфан рус формалистларының нәзари хезмәтләрен дә, форма үзгәрешенә нигезләнгән яңа агымнарны да (барыннан да элек имажинизм həм футуризм) аңлы рәвештә, поэтик яңарышка йөз тотып, максатчан кулланып карый. Ул татар шигъриятендә яңа образлылык тудыру мөмкинлеген нәкъ менә яңа агымнарга нисбәтле табып, аларны милли шигъриятне үзгәртү, камилләштеру юлы итеп карый башлый. Туфан катлаулы сурәтле образлылык тудыру белән мавыгып китә: билгеле күренешне эмоциональ бәя бирерлек төшенчә белән янәшә кую аша ассоциацияләр тудыра. Нәтижәдә «төн - кара сыер», «завод торбасыннан чыккан ялкын сыер муеныннан аккан кара кан» кебек символик детальләр белән чуарланган образлылык барлыкка килә; «Бодай күк бүрткән язгы уй / Шытылды / Казанның башында», «Безнең хисләр каный / Кимчелекне жиңмәү үченнән», «Әнкәй - авыл, әткәй - завод - кода, / Гареб - килен, / Кияү - Азия» кебек сурәтләр ярдәмендә яңа тормышны үзенчәлекле чагылдыру омтылышы ясый.

Х. Туфанның 1920 елларда ижат ителгән шигырьләрендә кабатлана барган «үткән бүгенге», «иске - яңа» кебек оппозицион вариантлар хасил була. Х. Туфан әлеге каршылыкны житкерүнең дә үзгә образлы юлларын һәм символик моделен тәкъдим итеп карый. «Арыш тавыш бирә» (1926), «Дачада» (1926), «Көнчыгышның яңа баласы» (1927), 
«Аккордлар» (1928-1930), «Еллар итәгендә» (1925), «Барабыз» (1925), «Татарстанда» (1925) h.б. шигырь-поэмаларының үзәгендә шушы каршылык ята. Мәсәлән, соңгы әсәрдә «үткән бүгенге» каршылыгы «элек һәм хәзер» кебек формалашып, аерым бүлекләр формасында поэма структурасында ук урын ала. Саз, губерна, кышлак кебек символик детальләр үткәннең билгесенә әйләнә, үткән - бәхетсезлек чыганагы, бүгенге - кешене бәхетле итә дигән фикер алга чыга, трактор, марш кебек бүгенгене тергезгән символик образ, сүзсурәтләр шушы мәгънәне төрле яклап көчәйтүгә хезмәт итә. Үткән - ханнардан калган кан кыры; көзге авылда кайгы йоту, нәләт әйтү, үксү; жир кешесе - кол; канлы пычаклар; кайгы; ятимлек; караңгы төн. Бүген - Татарстанның көнчыгыш белән көнбатыш туен уздыруы; авылны тракторлар тартуы; жир кешесе - хужа; күрешү маршы; көлү; Татарстан - әти; көн кебек детальләр үткәннең һәм бүгенгенең катлы-катлы образын тудыруда катнаша. Риторик эндәш төсендә аерып куелган хушлашу гыйбарәсе, саубуллашу белән бергә, үткәннән бөтенләйгә аерылу мәгънәсенә дә ишарә ясый. «Барабыз» (1925) шигырендә дә үткән-бүгенге каршылыгы үзәккә куелып, үткән - ат, кайгы, тынлык кебек образдетальләр аша тергезелә, бүгенге берничә образ-деталь ярдәмендә сурәтләнә: трамвай, паровоз, байрак, пропеллер, завод, барабан. Лирик геройның шатлыгы якты киләчәккә баруга бәйле: үткән тарих сагышлы, тын; бәхет исә индустриаль үсешкә бәйләнгән. Социализм тантанасы куанычы, индустриализация дәрте, иске тормышка нәфрәт, революцион яңаның жиңүенә тирән ышаныч, иске әдәбият белән бәхәс-полемика кебек күренеш-детальләр шушы шатлык хисен көчәйтү чарасына әверелә.

«Бөдрә көннәр» (1926) шигырендә Туфан революцион борылышлардан соң килгән иминлек елларының язын тасвир итә. Моннан тыш, шигырьдә яз символга әйләнә һәм, образның традицион мәгънәсен яңартып, якты, матур киләчәк эчтәлеге белән өретелә. Бүгенгенең матурлыгы ирек, хезмәт, кояш детальләре белән билгеләнеп, кояшлы язга илтүче юл якты киләчәккә бару юлы дип карала. «Еллар итәгендә» (1925) поэмасында «үткән - бүгенге» каршылыгы үзгә образлылыкка таянып житкерелә. Үткән сабый хәтерендә калыккан революция алды вакыйгаларын үз эченә ала, сагыш хисенең сәбәбен тәшкил иткән баланың әтисен югалту фажигасе, гомумиләшеп, ил, милләт, халык язмышына ишарә ясый. Үз фикерен житкерү өчен, шагыйрь символик образларга мөрәжәгать итә. Үткән белән бәйле жил илне туздыручылар, «тынычлыкны бозучылар» булып аңлашыла, тагын да гомумиләшеп, инкыйлабның үзен белдерә башлый:

\begin{tabular}{|c|c|}
\hline $\begin{array}{l}\text { Жил. Куе жсил. } \\
\text { Жил саламньь- } \\
\text { Ертылк йортның } \\
\text { йонын тарата. } \\
\text { Болытлар кар или. } \\
\text { Юлаучылар кайта }\end{array}$ & $\begin{array}{l}\text { «Себер». } \\
\text { Әмин белмим, } \\
\text { Нинди «Себер»дер?.. } \\
\text { Әжсил, жсил-себерке: } \\
\text { Жил кешеләрнен эзен } \\
\text { себерде [Туфан, б. 34]. }\end{array}$ \\
\hline каладан... (...) & \\
\hline
\end{tabular}

Социологик эстетика кысаларында кыш, төн кебек образ-детальләр дә үткән тормышның ямьсезлеген ачуга юнәлтелә, таң инкыйлаб китерәчәк якты киләчәкне белдерә. Бүгенге исә, өлкән «мин» хикәяләвендә тергезелеп, ирек, азатлык, көрәш, яңарыш һәм киләчәккә илтүче юл образ-детальләре аша житкерелә һәм шигырь яңа тормышның халыкка бәхет китерәчәге хакындагы идеяне раслый.

М.Жәлил ижатында чагылыш тапкан дөнья сурәте дә «үткән / бүгенге» каршылыгы аша тудырыла. Мәсәлән, «Үткән көннәрдән» (1924), «Әти үлгәч» (1924), «Безнең авыл» (1927) кебек шигырьләре яңа тормышны элекке чорны кире кагу аша данлый. Шигырь тукымасында корыган каен, карт сука символик образлары үткәннең югалуы, бетүе хакында хәбәр итсә, яшь каен, трактор образлары бүгенге һәм киләчәк билгесенә әверелә. «Сукачы угълы» (1923), «Боз ага» (1923), «Иске Себер жыры» (1924) кебек шигырьләр үткәнгә үкенеч белдереп, бүгенгене көрәш чоры итеп карап, аның белән горурланып языла, ач, авыру, эш белән ватылган «әти», «әни», «сука», «кара тормыш» кебек сүз-сурәтләр үткәннең билгеләренә әверелә. Бүгенгегә нисбәтле, Ленин, завод, трактор, туй-бәйрәм образдетальләре калка.

Яңа тормышны данлау мотивы алга чыккан лирик әсәрләрдә сәясәтчеләр образларының мифлаштырылуы дөнья мәдәниятендә билгеле булган архетиплар теориясе тәэсирендә бара. Билгеле булганча, идеологик эчтәлекле мифлаштыру күренешенә мөнәсәбәтле егерменче елларның икенче яртысыннан шигърияттә юлбашчы һәм бәхетле, якты киләчәк хакындагы мифлар активлаша. Ю. Борев фикеренчә, «XX гасыр өчен, гомумән, әхлакый-сәяси бердәмлеккә омтылу һәм юлбашчы, даһины югару күтәрү хас» [Борев, с. 
45]. 3. Фрейд күзаллаган ижтимагый төзелеш хакимият вәкилләрен күккә чөю, калганнарны Y3-үзләрен бәяли алмаучы, агымга ияреп яшәүче, тотрыксыз халәттә яшәүче кебек бәяләү - «юлбашчы - элита - масса» структурасы тормышка ашырыла. Шул рәвешле, XX гасыр башындагы милли идеалларны социалистик жәмгыять төзүче бөеклек, гаделлек, олылык символы буларак күтәрелгән, хәтта табыну үзәгенә әверелгән Ленин, Сталин образлары алыштыра. Мәсәлән, М. Жәлилнең «В.И. Ленин» (1930), «Уналтынчы удар» (1930), Ш. Маннурның «Сөекле рәсем» (1933) h.б. шигырьләрдә көрәшне житәкләүче Ленин образын изгеләштеру күзәтелә. Бераз соңрак М. Жәлил ижатында Киров, Сталин образларын мифлаштырган шигырьләр пәйда була («Сталинга» (1936), «Без кул күтәрәбез» (1937), «Сталин турында жыр» (1937) h.б.). Ш. Маннурның «Табыныр Аллам» (1937), «Халык улы» (1938) кебек шигырьләрендә юлбашчы образы архетип дәрәжәсенә күтәреп сурәтләнә.

«В.И. Ленин» (1930), «Уналтынчы удар» (1930) h.б. шигырьләрдә көрәшне житәкләгән Ленин образын изгеләштеру күренә, мифлаштыру барышында яктылык, кояш һәм ут символик образлары ярдәмгә килә. Акыллы карт архетибының үзенчәлекле модификациясе буларак, ул халыкны, дәүләтне алга жибәрүче, юл күрсәтүче юлбашчы итеп сурәтләнә. Әләм образы да Ленин әләме кебек уйнатыла. С.Хәкимнең «Мавзолей янында» (1938), «Ике лачын» (1938), «Скульптор мастерскоенда» (1938), «Жиде яшьлек дустым» (1939), «Шагыйрь өендә» (1939), «Гомер яңа башлана» (1939), «Володя ант итә» (1940) h.б. әсәрләрендә дә Ленин образы акыллы карт архетибын идеология кысаларына «буйсындырып» калыплаша. Мәсәлән, «Мавзолей янында» (1938), «Ике лачын» (1938), «Володя ант итә» (1940) h.б. шигырьләрдә яңа тормышны бүләк итүче Ленин образын изгеләштерү күренә, мифлаштыру барышында жил, зур юл, лачын həм кайнар ут символик образлары ярдәмгә килә. Шуның белән янәшәдә Сталин образын мифлаштыру тенденциясе дә урын ала. Әйтик, «Ике лачын» (1938) шигырендә шатлык хисе яңа тормыш төзү вакыйгасы белән янәшә тергезелә. Ике лачын - Ленин һәм Сталин шушы тормышны тәэмин итүче, яңа тормыш төзү идеясен дәвам итүче затлар итеп сурәтләнә. Бу фикер еш кына ике хакимнең үзара диалогы аша көчәйтелә. Шигырьдә юлбашчыларның дөньяга килүе - яңа тормыш киләчәге hәм дәвамчанлыгы, илнең бәхете хакында дөньяга хәбәр салу кебек тә аңлашыла.

Поэтик фикерләүдә халык авыз ижатына борылыш татар шигъриятендә фольклор символларының активлашуына китерә, шул сәбәпле 1930 елларның икенче яртысыннан татар шигъриятендә сыйфат үзгәрешләре пәйда була, поэтик яктан шагыйрьләр халыкчан фикерләүгә, классик шигырь традицияләренә, лириклыкка йөз белән борыла. Безнең карашыбызча, 1930 елларда символлар кулланылышының дәвам итүе, гомумән, татар әдәбиятында традицияләрнең көчле булуыннан килеп чыга. Бер яктан, татар поэзиясен фольклордагы халык акылы, фәлсәфәсе, фикерләү үзенчәлеге кызыксындырса, икенчедән, халык авыз ижатына хас романтик образлылык жәлеп итә, шулар нигезендә «фольклор стиле» калыплаша.

Халыкның поэтик фикерләвеннән килгән образларны, мотивларны һәм символларны куллану татар шигьриятенең борынгыдан килгән традицияләреннән файдалануга китерә. Фольклор катламына мөрәжәгать идеологик схематизмны читләтеп үтәргә мөмкинлек бирә: татар шагыйрьләре, күрәсең, поэтик яңарышны, чынбарлыкны сәнгатьчә тасвирлауда якынлыкны әлеге катламда таба һәм татар поэзиясе тематик яктан киңәя, тасвирлау чараларына байый. Шуның белән бергә халык жырларыннан алынган сурәтләр, табигать матурлыгы, жыр образы, төсләр символикасы активлаша: таң жиле, таң, жил, йолдыз кебек традицион романтик сурәтләр шигъри код, ачкыч сүз дәрәжәсенә күтәрелеп, лирик геройның эчке халәт, хис-кичерешләрен, теләкомтылышларын гәүдәләндерүгә юнәлтелә. Мәсәлән, М. Жәлилнең «Озату» (1934), «Сагыну» (1936), «Жир жиләгем» (1937), «Кушалмагач» (1937), «Чишмә жыры» (1938), «Жилләр» (1938), Ә. Фәйзинең «Умырзая» (1933), «Алмаларның якты кызыллыгы» (1937), «Көймә жыры» (1938), «Яшьлек» (1938), «Кыр казлары» (1940), Ә. Ерикәйнең «Таң жилләре кебек килермен дә...» (1935), «Чишмә суы челтери көмеш сыман...» (1936), «Салкын чишмә челтерәп ага...» (1937), «Зәңгәр күлен сагына-сагына...» (1938), «Мин китәрмен ахры еракларга...» (1938), Ш. Маннурның «Гайжан бабай» (1935), С.Хәкимнең «Юксыну» (1938), Х. Туфанның «Ак каен» (1933); «Луиза» (1929), «Озату» (1933) кебек лирик һәм лироэпик әсәрләре шул хакта сөйли. 
Мәсәлән, Х.Туфанның «Озату» (1933) шигырендә әлеге мотив илбасар белән көрәшкә китүче егет hәм аны озатучы чибәр кыз образлары аша тергезелә: кылыч, ярсу ат детальләре мотивның үзәген тәшкил итә, туган жирен саклау юлында үзен корбан итәргә әзер торган егет образы социалистик тормыш төзү өчен көрәш заманы чикләреннән чыгып китә. Кулъяулык очларына төйнәп, егеткә бүләк ителгән туган ил туфрагы, символик югарылыкка күтәрелеп, кызның егеткә кайнар мәхәббәтен, сөюнең дәрәжәсен дә, илнең егеткә булган ышанычын, аны кабат туган ил туфрагында күрергә теләүне дә романтик рухта житкерергә ярдәм итә.

Әлеге поэтик үзгәреш М. Жәлилнең «Хат ташучы» (1938) поэмасы мисалында да ачык күренә. Әсәрдә яңа тормышны данлау мотивы бригадир, иген үстерүче Фәйрүзә белән хат ташучы Тимербулатның мәхәббәт тарихына бәйле яктыртыла. Идеологик эчтәлекле сызыкта яңа тормыш төзүче шәхеснең рухи формалашу, житлегү тарихы үзәккә алынып, патриотизм рухында хәл ителә, совет чынбарлыгын мактау белән үрелеп китә. Шуның белән янәшәдә мәхәббәт сызыгында халык жырларыннан алынган тасвирый чаралар мәхәббәтнең гүзәллеген ачуга юнәлтелә: «Буе зифа тал кебек, / Йөзе алсу таң кебек. / Йөз карашы Чулпан кебек, / Сүзе татлы бал кебек», «Ялкын күзле Фәйрүзәкәй һәркемгә якын иде» h.б.

Х. Туфанның композицион яктан ак каен белән Хәйбулланың сөйләшүе рәвешендә ижат ителгән «Ак каен» (1933) шигырендә исә образлар бирелеше, ак каенның әңгәмә-диалогы шулай ук халык жыры формасына нигезләнә. Шигырьдә көрәш мотивы гражданнар сугышы фажигасенә бәйле күтәрелә, риторик сорау һәм риторик эндәш алымы ярдәмендә кайгының эчтәлеге ачыла: Хәйбулланың аклар тарафыннан ак каенга асылуы лирик герой кайгысына сәбәп була, ак каен образы, халык жыры традицияләрен яңартып, кайгы, сагыш, хәсрәткә ишарәли, каенның яшел яфракларын кою сурәте хиснең дәрәжәсен күрсәтә.

Халык мифологиясеннән килгән образларны ил, аның язмышы белән мөнәсәбәттә куллану тагын да көчәя. Шуның нәтижәсендә күп кенә шигырьләрдә «ил» төшенчәсенең милли эчтәлеге калкытыла. Әлеге яңарыш чор поэзиясендә М. Жәлил ижатында аваз сала. «Туган илем, якты өем» дип белдерүче лирик геройның сагышы, аңа омтылыш хисе карлыгач, алтын балык, көмеш яллы житез аргамак кебек милли-мифологик образлар ярдәмендә күрсәтелә. Гөл чәчәкләре, таң жиле, чык төшкән үләннәр, Чулпан йолдыз, куш алмагач кебек традицион образ-детальләр «яңа тормыш өчен көрәшүче ил» образын «татарлар яши торган ил»гә әверелдерергә мөмкинлек бирә.

Әйтик, М. Жәлилнең «Ана» (1938), «Алтынчәч» (1940) кебек шигырь-либреттоларында ил образы Ватан-ана сыйфатында тәкъдим ителә башлый. Жирән кашка, урман, өянке, ал чәчәкләр детальләре шулай ук милли яңгыраш хасил итә. Әлеге үзенчәлек туган ил образының бирелешендә дә ачык күренә: М. Жәлил татар поэзиясенә туган ил - татар жире дигән караш алып килә. Н. Исәнбәтнең «Туган ил», К. Нәжминең «Туган йортыбыз», Г. Кутуйның «Талантлар Ватаны», А. Алишның «Туган илгә» кебек шигырьләрендә дә әлеге мәгънә күзәтелә. М. Жәлилнең «Моабит дәфтәрләре» циклында Ананы мифлаштыру күренеше, туган ил - табигать - туган жир ана чылбыры пәйда була. «Шагыйрь» (1942), «Юллар» (1943), «Яшь ана» (1943) кебек лирика үрнәкләрендә Ана образы туган ил, кешелеклелек белән тәңгәлләштерелә.

M. Жәлил шигырьләрендә батырлык мотивы да еш кына фольклор символлары ярдәмендә белдерелә. Мәсәлән, «Ана бәйрәме» (1943) балладасында әкияттәгечә өч ул, аларның икесе яуда башын салу, «алмаз кылычлы» өченче улның жиңеп кайтуы, хәбәр китерүче жил һәм күгәрчен, кайгыдан сукырайган ананың күзләре ачылу кебек мотивлар ил өчен көрәшне данлауга хезмәт итә. «Сандугач һәм чишмә» (1942) балладасында аллегорик образлылык шулай ук ил азатлыгы хакына корбан булу фикерен калкыта, табигать матурлыгы үлемнең ямьсезлеген көчәйтүгә хезмәт итә. «Кызыл ромашка» (1942) балладасында батырлык иң югары кыйммәт дәрәжәсенә куелып, илгә тугрылык, батырларча ныклык ромашка образы аркылы житкерелә.

Бу сыйфат үзгәреше көрәш мотивына нисбәтле көрәшче-батыр, егет-татар егете схемасында да чагылыш таба. Халык авыз ижатыннан үстерелә килгән алымнар ярдәмендә сурәтләнгән әлеге образ 1920 еллар шигъриятенең көрәшче мифологик образын соцреализмның норматив кысаларыннан алып чыга. Мәсәлән, М. Жәлинең «Батыр егет турында жыр» (1936), Х. Туфанның «Ак каен» (1933), Ф. Кәримнең «Яшен яктысы» (1932) 
шигырьләрендә кулланылган акбүз ат, үткен кылыч, яшен чаткысы детальләре ярдәмендә батыр егет образы милли-мифологик төсмерләр белән баетыла, татар әкиятләреннән күчкән кыю көрәшчегә әверелә.

M. Жәлил әсәрләренең үзәгендә торган архетипик герой-көрәшче образы да үзгә сыйфатларда күренә: илне яклап көрәшкән батыр, тугры сугышчы; шагыйрь-герой. Мәсәлән, «Шагыйрь» (1942) шигырендә ул ижаты белән давылны жиңүгә өлеш керткән гадәттән тыш кеше рәвешен ала. «Була кайчак» (1943), «Жырларым» (1943) кебек шигырьләрдә ил бәйсезлеге хакына корал тотып көрәшкән, жырлары белән меңнәрне көрәшкә күтәргән каһарман, гомерен, ижатын һәм үлемен ил азатлыгы өчен дип белдергән әйдаман төсендә пәйда була.

Сугыш чоры татар шигъриятендә фольклор образлары лирик герой хисләренең сынлы рәсемен тудыру максатыннан да, фәлсәфи фикерләрне һәм автор позициясен житкерүче символик яки аллегорик образлар статусында да, туган жирне сагыну һәм ярату тойгысының гәүдәләнеше булып та кулланыла. Мәсәлән, Ф. Кәримнең тынычлык / сугыш оппозициясенә корылган «Бездә яздыр» (1942) шигырендә шагыйрь ике дөньяны - фашистлар кулындагы hәм илнең тыныч жирләрен каршы куеп сурәтли. Сугыш һәм матурлыкның антиномияce, гомумән, Ф. Кәрим яратып кулланган алымнарның берсе булып тора. Хат-монолог формасында ижат ителгән шигырьдә яз образы өмет, яңару, якты киләчәк символына әверелә. Шигырь тукымасында үз-үзе белән каршылыкка кергән яз образы аша Ф.Кәрим гомумиләштерелгән фикерен, фәлсәфәсен житкерә: фашизм кешелекне генә түгел, табигатьнең матурлыгын, асылын да юкка чыгара. «Сибәли дә сибәли» (1942) шигырендә исә көзге яңгыр образы якын иптәшен югалту хәсрәтеннән газапланучы лирик герой кичерешләрен ассызыклый. Көзгеле композициягә корылган әсәр тукымасында сибәли дә сибәли рефренының кабатлануы, сынландыру алымы, трагик пафос, кабатлау композицион алымы, үзенчәлекле метафора-эпитетлар - барысы да сугышчы-лирик геройның хис-кичереш дәрәжәсен көчәйтү, фажигалелек мотивын тирәнәйтү чарасына әверелә.

Шул ук вакытта халык авыз ижатына мөрәжәгать, символик фикерләүнең чишмә башында торган фольклор образларыннан [Халит, б. 139] үсеп чыккан символлар читлә- теп әйтүләрнең, идеологик басымнан качуның бер чарасы кебек аңланыла башлый. 1930 елларның икенче яртысыннан шагыйрьләрнең дөнья барышын, жәмгыять үсешен тирәнрәк аңлый баруы, идеологиягә мөнәсәбәте үзгәрүе милли шигъриятнең яңа төсмерләр белән баюына этәрә: символик образлар аркылы жәмгыятькә житлеккән караш сизелә башлый, лирик геройның эчке дөньясын тасвирлауга игътибар арта. Л.А. Колобаева фикеренә таянып, без әлеге күренешне «ижтимагый барышны алдан күру һәм бәяли алу тенденциясе» [Колобаева, 1991, с. 216] дип атыйбыз. Мондый шартларда, кагыйдә буларак, эзоп теле, яшерен эчтәлек алымы активлаша. Фольклор символлары, катгый сәяси кагыйдәләргә генә буйсынмыйча, авторларның алып барылган идеологиягә каршы фикерләрен, ижтимагый-сәяси барышка объектив бәясен житкерә башлый.

Аерым шагыйрьләрнең дөньяга карашында, үзе нык инанган идеологиягә мөнәсәбәтендә хасил булган үзгәрешләр нәтижәсе әсәрләренең эчтәлегендә дә күзәтелә башлый. Совет системасына, хакимият вәкилләренә тәнкыйди караш, яңа тормышның көнүзәк проблемаларын яшәеш, милләт язмышы, халык әхлагы hәм традицияләре нокталарыннан күздән кичеру поэзиянең гражданлык эчтәлеген тирәнәйтә. Тарихи чор, ижтимагый вазгыять белән бәйле әсәрләрдә сәяси барышка бәя пәйда була, әмма болар ешрак яшерен эчтәлек, киная, эзоп теле, символлаштыру ярдәмендә мәйданга чыга.

Бу күренеш социологик ноктадан да аңлатыла ала. Л.А. Колобаева фикеренчә, символ, иң беренче чиратта, жәмгыять, дөнья һәм милләтнең торышына, киләчәгенә прогноз буларак чыгыш ясый, мондый төр символлар аеруча әдәбиятның, ижтимагый-фәлсәфи, сәяси фикернең борылышы чорында, рухи һәм сәяси баскынчылык вакытында көчәяләр [Колобаева, 1991, с. 216], чөнки бу вакытта яшерен тел, табу - тыю принциплары эшли башлый. Әлеге фикерләр 1930 еллар татар шигърияте мисалында бигрәк тә дәлилле яңгырый, чор поэзиясендә символларның функциясен, кулланылыш мөмкинлекләрен ачып бирә: әдипләр аерым берләрен сәяси эчтәлек белән баета, субъектив эчтәлектә яшәп килүче идеологиягә, яңа тәртипләргә бәя бирүгә юнәлтә. Әлеге яңарыш шәхес концепциясендәге алмашынуга да йогынты ясый. Мондый эчтәлектәге шигъри әсәрләрдә лирик геройның 
статусы үзгәреп, үз карашы, мөнәсәбәте булган, тормыш-яшәешкә бәя бирергә, анда кешенең урынын ачыкларга омтылган лирик герой мәйданга чыга.

Әлеге сыйфат үзгәреше, безнең фикеребезчә, иң беренче нәүбәттә, h. Такташ ижатында мәйданга чыга. «Ертык бүрек» (1927), «Болай гади жыр гына...» (1928), «Ак чәчәкләр» (1929), «Ай кебек без озак яшәмәбез» (1928) кебек шигырьләрендә символлар аша лирик герой үзе нык ышанган идеологиянең ялган булуы хакында сүз башлый. Жил, кышкы салкын кебек символик образ-сурәтләрнең татар шигъриятендә активлашуы да Такташ әсәрләреннән башлана.

Ә. Фәйзинең «Умырзая» (1933), «Яшьлек» (1938), «Көз» (1939), «Яфрак һәм чикләвек» (1939), Ф. Кәримнең «Еллар үтә, ерагая бара» (1940), «Кыр казы» (1941), «Көзге яңгырлы төн... » (1939) кебек шигырьләрендә ике төрле укылышка ия символик образ-детальләргә мөрәжәгать ителеп, кешенең кыйммәте, рухи матурлыгы, жәмгыятьтәге урыны халкына китергән файдасы белән бәяләнә башлый. Лирик герой яңа тормыш төзу юлындагы ялгышлар хакында сөйли, метафора, символ, эпитетлар сәяси барышка бәя бирү вазифасын башкара.

Х. Туфанның «Сүзсез генә» (1937), «Ә йолдызлар дәшми» (1937) шигырьләрендә лирик герой сәясәт, идеологиянең ялган булуы хакында сүз алып бара. Мәсәлән, «рухи азатлык - фикри тоткынлык» каршылыгына корылган «Ә йолдызлар дәшми» (1937) шигырендә лирик герой яңа тормыш төзүдәге хаталар турында сөйли, «иң кадерле эре ирләрне дөмгә сөйрәгән» эпитеты сәяси барышка бәя бирә. «Ваемсыз жилнең кереп, дәверне, кибәннәрне туздыруы» сурәте борчылу хисенә сәбәп төсен ала. Автор фикере бу сурәттәге советчыл идеологияне гәүдәләндергән ваемсыз жсил; зыялыларга ишарә булган кибән түбәсе; ялагай, Үз фикере, карашы булмаган халыкны белдергән кибәк символлары аша тирәнәйтелә. Чынбарлыкны үзгәртә алмаудан газапланган лирик герой, юаныч эзләп, йолдызларга мөрәжәгать итә, ләкин аларның да дәшмәве чарасызлыкка ишарәли. Шигырь тукымасында лирик герой шушы хәлләрдән риза булмаган, аларны үзгәртү омтылышы белән яшәүче көрәшче булып кабул ителә.

«Агыла да болыт агыла» (1951) шигырендә туган жиреннән аерылырга мәжбүр ителгән лирик герой hәм тирәлекне гәүдәләндерүче битараф болыт мөнәсәбәтләрен сурәтләу аша жәмгыятьнең, тирә-юньдәгеләрнең шәхес культы алып килгән үзгәрешләрне күрмәмешкә салышуына хәсрәтләнү хисе белдерелә. Лирик герой белән гомернең узуын, язмышны чагылдырган болыт образлары ирек белән ирексезлекнең билгеләренә әверелә. «Нәрсә әйтер туганнарыма?» риторик соравының, «агыла да болыт агыла» тезмәсенең кабатлануы композицион яктан шигырьне туплап торучы үзәк хезмәтен үтәсә, бер үк вакытта хәсрәтнең дәрәжәсе көчәюне тәэмин итә, хәтта интонация үзгәреше, гомер юлына иронияле бәя дә шул максатка юнәлтелә.

«Илдә ниләр бар икән?» (1944) шигыре дә якыннарыннан аерылган, изоляциядәге кешенең үзен каһәрләгән ил язмышын кайгыртып хәсрәтләнүен ассызыклый, образсимволлар аша лирик герой халәтен, автор бәясен төгәлләштерә. Лирик геройның билгесезлектә яшәве, ялгызлыгы, өметләренең акланмаячагын белү ил, халык фажигасен бәяләүгә кадәр үстерелә: Илдә ниләр бар икән: / Юллар зәнцгәр кар микән? / Һавадагы алсу шәүлә /Пожар микән, таң микән? / Илдә ниләр бар микән? [Туфан, б. 233]. Шигырьнең беренче строфасында кулланылган зәңъгәр кар, пожар, таң образлары, кабатланып, символ дәрәжәсенә куела: зәңгәр кар һәм таң лирик геройның якты киләчәккә өметләрен, пожар илдә барган канлы вакыйгаларны символлаштыра. Шагыйрьнең «Авырган минутларда» (1942), «Хәят» (1942) h.б. лирик үрнәкләрендә дә яңа идеологиянең кешелексезлеген, ижтимагый-сәяси вазгыятьне «эзоп» теле аша тасвирлау урын ала.

Шул рәвешле, 1920-1950 еллар татар шигъриятендә символлар системасын күзәтү, анализлау сүз сәнгатендә барган күп кенә процессларны төгәлләштерергә мөмкинлек бирә. Ул әдәбиятның үзгә, башкалардан аерым, милли сукмаклар салып үсәргә омтылышын ачык күрсәтә. Сүз сәнгатенең халык авыз ижатына мөрәжәгате, татар әдәбиятының традицион образларын идеологик-мифологик сурәтләрнең детальләре төсендә куллануы сәяси чикләүләрне урап үтәргә мөмкинлек бирә. Фольклор белән бәйләнешләр тәэсирендә татар шигърияте шәхси эмоциональлек, милли рух белән өретелә. Шуның белән янәшәдә яшерен эчтәлек алымының активлашуы поэзиядә субъектив катламны тирәнәйтә һәм әдипләрнең яшәп килгән тәртипләргә мөнәсәбәтен калкуландырырга мөмкинлек бирә. 
Вакыты белән үзенең генетик асылыннан читләшеп, социологик, ижтимагый-сәяси эчтәлек белән сугарылса да, поэтик фикерләүдә халык авыз ижаты образларына, сүз сәнгате тарихыннан таныла торган мотивларга, алымнарга әйләнеп кайту күренеше үзе үк әдәби традицияләрнең дәвам ителешен, үстерелешен, мәгънәви баетылышын дәлилли hәм сүз сәнгатенең классик нигезләрне, кыйммәтләрне югалтмавы хакында сөйли. Шулай итеп, әдәби барышта XX гасырның алтмышынчы елларында булачак өченче «шартлау»га, тәнкыйди башлангычның көчәюенә жирлек әзерләнә, ул сүз сәнгатенең бик тирән катламнарында барлыкка килеп, яңарыш башлану белән калкып чыга.

\section{Әдәбият}

Бурнаш Ф. Әдәбият һәм сәнгать турында. Казан: Татар. кит. нәшр., 1978. 238 б.

Галимуллин Ф.Г. Эстетика һәм социологизм: 20 30 нчы еллар татар әдәбиятында эстетика кануннарының һәм социологизм таләпләренең үзара мөнәсәбәте. Казан: Мәгариф, 1998. 223 б.

Жәлил М. Алтынчәч // Әсәрләр: 4 томда. Т. 2. Казан: Татар. кит. нәшр., 1976. Б. 251 - 322.

Ибраһимов Г. Татар әдәбияты (2) (Еллык хисап урынында) // Әсәрләр: 8 томда. Т. 5. Казан: Татар. кит. нәшр., 1978. Б. $404-419$.

Нигъмәти Г. Утыз беренче елга кергәндә // Яңалиф. 1931. № 1. Б. $36-41$.

Мөсәгыйть Ф. Редакциягә хат. Татар опера студиясе турында // Кызыл Татарстан. 1937. 21 август.

Такташ h. Әсәрләр: 3 томда. Т.1. Казан: Татар. кит. нәшр., 1980. 352 б.

Туфан Х. Әсәрләр: 5 томда. Т. 1. Казан: Татар. кит. нәшр., 2007. 479 б.

Балашова Ю.Б. Русская литература XX века: история, художественная идеология, поэтика: учебное пособие. СПб.: Высш. шк. журн. и мас. коммуникаций, 2016. 124 с.

Бертельс A.E. Художественный образ в искусстве Ирана IX-XV веков (Слово, изображение). М.: Издательская фирма «Восточная литература» РАН, 1997. $422 \mathrm{c}$.

Борев Ю.Б. Особенности литературы в ХХ веке // Теория литературы. Т. 4: Литературный процесс. М.: ИМЛИ РАН, 2001. С. 456 - 469.

Гачева А.Г. Философский контекст русской литературы 1920 - 1930-х годов. М.: ИМЛИ РАН, 2003. $400 \mathrm{c}$.
Голубков М.М. Утраченные альтернативы: Формирование монистической концепции советской литературы. 20-30-е годы. М.: Наследие, 1992. $202 \mathrm{c}$.

Голубков М.М. Русская литература XX века: После раскола. М.: Аспект Пресс, 2001. 267 с.

Гюнтер $X$. Тоталитарное государство как синтез искусств // Соцреалистический канон: сб. статей / под общ. ред. Х.Гюнтера и Е.Добренко. СПб.: Академический проект, 2000. С. 7. - 15.

Загидуллина Д.Ф. Модернизм в татарской литературе первой трети XX века. Казань: Тат. кн. издво, 2013. 207 c.

Клинг O.A. Влияние символизма на постсимволистскую поэзию в России 1910-х годов: проблемы поэтики. М.: Дом-музей Марины Цветаевой, 2010. $356 \mathrm{c}$.

Колобаева Л.А. Символ как хранитель и возмутитель классических традиций (образ Дон-Жуана в русской литературе конца XIX - начала XX века) // Классика и современность. М.: Изд-во МГУ, 1991. C. $207-216$.

Колобаева Л.А. Русский символизм. М.: Изд-во МГУ, 2000. $296 \mathrm{c}$.

Нигматуллина Ю.Г. Типы культур и цивилизаций в историческом развитии татарской и русской литератур. Казань: Изд-во «Фэн» АН РТ, 1997. $192 \mathrm{c}$.

Саруханян А.П. К соотношению понятий «модернизм» и «авангардизм»// Авангард в культуре XX века (1900-1930 гг.): Теория. История. Поэтика: в 2 кн. Кн.1. М.: ИМЛИ РАН, 2010. С. 9 - 33.

Семенова С.Г. Русская поэзия и проза 19201930-х годов. Поэтика - Видение мира - Философия. М.: ИМЛИ РАН, «Наследие», 2001. 590 с.

Стеиенко E.A. Концепты хаоса и порядка в литературе США. От дихотомической к синергетической картине мира. М.: ИМЛИ РАН, 2009. 264 с.

Хабутдинова М.М. Проблема личности в творчестве Х.Такташа: дис. ... канд. филол. наук. Казань, 1998. $181 \mathrm{c}$.

Хализев В.Е. Теория литературы: учебное пособие. М.: Высш. шк., 2000. 398 с.

Халит Г.М. Поэзия дерзаний. Казань: Тат. кн. изд-во, 1980. $160 \mathrm{c}$.

Юсупова Н.М. Фольклорные символы как источник символизации у татар (на материале орнитоморфной и цветовой символики) // Вестник Рязанского государственного университета имени С.А. Есенина. 2016. № 4 (53). С. 138-145. 


\title{
СИМВОЛЫ В ТАТАРСКОЙ ПОЭЗИИ 1920-1950-Х ГГ.: РАЗНОВИДНОСТИ, ФУНКЦИИ И НОМИНАТИВНЫЕ ЗНАЧЕНИЯ
}

\author{
Нурфия Марсовна Юсупова, \\ Казанский федеральный университет, \\ Россия, 420008, г. Казань, ул. Кремлевская, д. 18, \\ faikovich@mail.ru.
}

\begin{abstract}
В статье анализируется символическая система на материале татарской поэзии 1920-50-х годов. Основным объектом исследования стали поэтические произведения Х. Такташа, М. Гафури, Х. Туфана, М. Джалиля, А. Файзи, Ф. Карима и др. В ходе анализа нами выявлены национально-специфические особенности символизации в татарском словесном искусстве. Несмотря на то что в 1920-е годы татарская поэзия начинает функционировать как одна из отраслей социалистической культуры, связь с прошлым окончательно не обрывается во многом благодаря устойчивым традициям в татарской поэзии, которые сформировались в начале XX века. Наблюдается обращение к образам, мотивам и символам, восходящим к народной или исламской культуре, общетюркской мифологии. Техника символизации совпадает с механизмом внутрилитературного синтетизма.

С другой стороны, смена литературно-эстетических и социокультурных ориентиров служит основой для возникновения идеологических символов. Зачастую в данном ключе функционируют и сквозные для татарской литературы символы, но в ходе трансформаций в текстах появляются их многочисленные авторские смысловые вариации. В-третьих, фольклорные образысимволы воспринимаются татарскими поэтами как возможность «смягчения» резких переходных явлений и сохранения при этом содержательных и формальных художественных традиций национальной поэзии. Обращение к народному творчеству, использование традиционных для татарской литературы образов-символов в качестве деталей идеолого-мифологических образов позволили поэтам преодолеть политический схематизм. В-четвертых, в фольклорных образахсимволах прослеживается осознанный взгляд на идеологию, они выступают «выразителями» «противоидеологической» авторской позиции. Критический взгляд на повседневные проблемы жизни сквозь призму судьбы нации, нравственности и традиций народа приводит к углублению содержания - так в татарской поэзии 1920-50-х годов проявляется политический подтекст.

Таким образом, с одной стороны, смена социокультурных ориентиров способствует поиску идеологических универсалий, символических структур для формирования идеологического содержания, с другой стороны, татарская поэзия пытается оберегать прежние литературные традиции, что ярко проявляется в сохранении фундамента системы национальных символов, прежде всего при помощи генетически связанных с фольклорными традициями образов-символов, продолжающих традиции символизации начала XX века.
\end{abstract}

Ключевые слова: татарская поэзия, символ, трансформация, образ, концепция личности, функция, номинативное значение.

Исследование выполнено в рамках гранта РФФИ и Правительства Республики Татарстан (научный проект № 18-412-160008). 